NASA Technical Memorandum 83762

\title{
Microstructure and Surface Chemistry of Amorphous Alloys Important to Their Friction and Wear Behavior
}

Kazuhisa Miyoshi and Donald H. Buckley

Lewis Research Center

Cleveland, Ohio

Prepared for the

1985 International Tribology Conference sponsored by the Japan Society of Lubrication Tokyo, Japan, July 8-10, 1985 
MICROSTRUCTURE AND SURFACE CHEMISTRY OF AMORPHOUS ALLOYS IMPORTANT TO THEIR FRICTION AND WEAR BEHAVIOR

Kazuhisa Miyoshi and Dona id H. Buck ley*

ABSTRACT

An investigation was conducted to examine the microstructure and surface chemistry of amorphous a lloys, and their effects on tribologica 1 behavior.

The results indicate that the surface oxide layers present on amorphous alloys are effective in providing low friction and a protective film against wear in air. Clustering and crystallization in amorphous alloys can be enhanced as a result of plastic flow during the sliding process at a low sliding velocity and at room temperature. Clusters or crystallites with sizes to $150 \mathrm{~nm}$ and a diffused honeycomb-shaped structure are produced on the wea $r$ surface. Temperature effects lead to drastic changes in surface chemistry and friction behavior of the alloys at temperatures to $750^{\circ} \mathrm{C}$. Contaminants can come from the bulk of the alloys to the surface upon heating and impart to the surface oxides at $350^{\circ} \mathrm{C}$ and boron nitride above $500^{\circ} \mathrm{C}$. The oxides increase friction while the boron nitride reduces friction drastically in vacuum.

\section{INTRODUCTION}

Metallic glasses are currently finding increased application in the aerospace industry [1]. They are used for joining internal assemblies in gas turbines. Nickel-based brazed foils of the BNi class are replacing the more expensive gold-based BAu-4 foils in engine valves and many other components. However, like BAu-4, the nickel-based filler meta is have excellent flow behavior, are compatible with most stainless steels and nickel alloys, and offer an outstanding combination of high-temperature strength, fatigie properties, and oxidation and corrosion resistance [1].

A combination of favorable mechanical and physical properties makes metallic glasses candidates for other technological applications. For example, the combination of high permeability and high hardness makes these materials suitable for use in highly developed magnetic recording devices (e.g., video tape recorders). In most high-density devices, a magnetic head in sliding contact with a magnetic tape is used for recording and playback. Therefore, the magnetic head and tape must have good wear resistance.

*National Aeronautics and Space Administration, Lewis Research Center, Cleveland, Ohio 44135
Metallic glasses can also be used in foil bearings. The highly disordered structures of metallic glass would be resistant to radiation damage, and, thus, have potential for use where constant mechanical properties are required under irradiation. The mechanical and physical properties of metallic glasses are, therefore, of basic scientific interest. Metallic glasses have several properties that make them attractive for tribologica 1 . applications. These properties include great adhesion, shear strength, impact penetration, corrosion resistance, stiffness, and ductility. Relatively little research, however, has been done on the friction, adhesive wear, and abrasive wear properties of the metallic glasses [2-7].

This paper is principally concerned with a fundamental understanding of microstructure and chemistry of amorphous a lloy surfaces, and their effects on tribologica 1 properties (friction and wear). Sliding friction experiments were conducted with three ferrous-base amorphous a lloy compositions in vacuum ( $30 \mathrm{nPa}$ ) and a laboratory a ir or a rgon a tmosphere. A rider of a luminum oxide was made to slide on the amorphous a lloy surfaces under loads of from 0.1 to $2.5 \mathrm{~N}$ and at sliding velocities of from 0.033 to $0.17 \mathrm{~mm} / \mathrm{sec}$. The vacuum experiments were conducted at temperatures of from room to $750^{\circ} \mathrm{C}$. 


\section{MATERIALS}

Three amorphous alloy compositions were examined in this investigation. The compositions and some of their properties are presented in table I. The alloys were foils ( 30 to $33 \mu \mathrm{m}$-thick ribbon), and were used in the as-cast condition. The spherical riders that were made to slide on the foil." were single-crystal a luminum oxide (sapphire) spheres and the diameter of the spheres were 3.2 and $6.4 \mathrm{~mm}$.

\section{APPARATUSES}

Two apparatuses were used in this investigation (Fig. 1). They both use a pin on flat configuration. One consists of an ultra-high vacuum system capable of measuring adhesion, load, and friction and conta ins an XPS spectrometer. Figure 1(a) indicates the major components, including the electron energy analyzer, the X-ray source, and the ion gun used for ion sputter etching. A manipulator-mounted beam was projected into a vacuum chamber. The beam conta ined two flats machined normal to each other with stra in gages mounted thereon. The load was applied by moving the beam normal to the flat and was sensed.by strain gages. The vertical sliding motion of the pin along the flat surface was accomplished through a motorized manipulator assembly. The friction force under, an applied load was measured during vertical translation by a stra in gage mounted norma 1 to that used to mea sure load.

The second apparatus used in this investigation is shown schematically in Fig. 1(b). The pin was made to traverse a distance of $10 \mathrm{~mm}$ on the surface of the foil. Motion was reciproca 1. The pin was loaded a ga inst the foil with dead weights. The arm retaining the rider conta ined stra in gages to mea sure the tangential and normal forces. The entire apparatus was housed in a plastic box.

\section{EXPERIMENTAL PROCEDURE}

Specimen Preparation and Heating

The foil specimen was attached to an insulator flat with tantalum supporting sheets (Fig. 1). The specimen was directly. in contact with the sheets. The flat and pin surfaces were rinsed with 200-proof ethyl alcohol just before they were placed in the vacuum chamber. After the specimens were placed in the vacuum chamber, the system was evacuated and then baked out at $250^{\circ} \mathrm{C}$ to obta in a pressure of $30 \mathrm{nPa}\left(2 \times 10^{-10}\right.$ torr $)$ or lower.
Both flat and pin specimens were argon ion sputter cleaned. Treatment was next conducted in situ, and this included heating to a maximum temperature of $750^{\circ} \mathrm{C}$ at a pressure of $600 \mathrm{nPa}$ for 20 to $30 \mathrm{~min}$. The foil was resistance heated. The temperature was measured with a type $\mathrm{K}$ ( $\mathrm{Ni}-\mathrm{Cr}$ versus $\mathrm{Ni}-\mathrm{Al}$ ) thermocouple in contact with the specimen. Specimens were thinned for transmission electron microscopy and diffraction studies by ion-etching and electropolishing.

\section{Surface Chemical Analys is}

The foil surfaces were analyzed by $X$-ray photoelectron spectroscopy (XPS). The depth analys is with XPS is of the order of 2 to 3 $\mathrm{nm}$, and the ultimate sensitivity is sufficient to allow fractions of a monolayer to be detected and identified. A magnesium $K_{\alpha} X$-ray source was used with an X-ray source power of $400 \mathrm{~W}$. All XPS analyses were conducted at room temperature.

\section{Friction Experiments}

In the ultra-high-vacuum system, in situ friction experiments were conducted with the surface-treated foil specimens over a temperature range of from room to $750^{\circ} \mathrm{C}$. A load of $0.2 \mathrm{~N}$ was applied to the pin-flat contact by deflecting the beam, as shown in $\mathrm{Fig} .1$. To obta in consistent experimenta 1 conditions, contact before sliding was ma inta ined for 30 sec. Both the load and friction force were continuously monitored during a friction experiment. Sliding velocity was $3 \mathrm{~mm} / \mathrm{min}$ with a total sliding distance of 2 to $3 \mathrm{~mm}$. All single-pass friction experiments were conducted in a $30 \mathrm{nPa}$ vacuum. The coefficients of friction reported herein were obta ined by averaging three to five mea surements.

In argon or a laboratory a ir a tmosphere the foils of the amorphous alloys and the pin specimen surfaces were scrubbed with levigated a lumina, rinsed with tap water and then with distilled water, and finally rinsed with ethyl alcohol. After the surface was dried with argon gas, the specimens were placed into the experimenta 1 apparatus. The specimen surfaces were then brought into contact and loaded, and the friction.experiment was begun.

\section{RESULTS AND. DISCUSSION}

Amorphous Alloy Surfaces

To establish the exact crystalline state of the amorphous a lloy surfaces, microstructure was examined by transmission electron 
microscopy and diffraction in a microscope operating at $100 \mathrm{kV}$.

A typical example of the structure of the as-received amorphous alloy foil is shown in Fig. 2. The amorphous alloy lacks the macroscopic structural features common in crystalline metals. In the absence of macroscopic crystallinity, neither gra ins, gra in boundaries, gra in orientations nor additiona 1 phases exist. However, black spots, which are believed to be nuclei and/or crystallites with a size range to $4 \mathrm{~nm}$, are apparent in the photomicrograph. Very diffused honeycomb-shaped structures formed by dark grey bands as a result of segregation and clustering of transition metals and meta 1loids are a lso apparent in the

photomicrograph.

The electron diffraction pattern for the as-received foil presented in Fig. 2 indicates that the amorphous alloy foil was not completely amorphous but conta ined extremely small nuclei and/or clusters of approximately a few nanometers in size.

All the XPS spectra taken from the surfaces of three amorphous alloys as received clearly revea led adsorbed oxygen and carbon contaminants in addition to the various a 1loying constituents of the nominal bulk composition. Beneath this layer of adsorbate there is a mixture layer of oxides of the alloying constituents.

$\mathrm{Fe}_{2 \mathrm{p}}$ peaks of the as-received $\mathrm{Fe}_{67} \mathrm{C}_{018} \mathrm{~B}_{14} \mathrm{Si}_{1}$ specimen are shown as an example in Fig. 3. The spectrum for the surface before cleaning clearly indicates that there were iron oxides such as $\mathrm{Fe}_{2} \mathrm{O}_{3}$ on the foil surface. The spectra taken after the foil surface had been argon sputter cleaned for 2 and 4 min reveal that the lines for Fe2p were split a symmetrically into doublet peaks. The doublet peaks are associated with. iron oxides and iron. The spectra taken after the foil surface had been argon sputter cleaned for 60 min clearly indicate the $\mathrm{Fe}_{2 \mathrm{p}}$ peaks associated with iron, while the iron oxide peak is very sma 11. The results at 30 min sputtering were similar to those at $60 \mathrm{~min}$.

The as-received $\mathrm{Fe}_{6} \mathrm{C}_{0}{ }_{18} \mathrm{~B}_{14} \mathrm{~S} \mathrm{~S}_{1}$ foi 1 contained the oxides of cobalt, boron and silicon as well [2]. The oxide layers are extremely important for amorphous alloys from a tribological point of view, because it is very hard and tenaciously bonded to the alloying constituents. This can provide good wear resistance, and will be discussed in the following section.

The XPS spectra of the surface argon sputtered for 60 min conta ined sma 11 amounts of carbide and oxide contaminants such as silicon carbide and silicon dioxide, although the $\mathrm{Fe}_{67} \mathrm{Co}_{18^{B}}{ }_{14} \mathrm{Si}_{1}$ foil was not supposed to conta in carbon and oxygen. The contaminants (i.e., oxygen and carbon) ma be introduced from the environment into the bulk of the alloy and form bulk contaminants, such as carbides and oxides, in the alloy during the casting process.

The argon-ion-sputter cleaned surface conditions of the three amorphous alloy foils a nalyzed by XPS are summarized in table II. The relative concentrations of the various constituents on the surfaces were different from the nominal compositions.

\section{Friction and Wear}

Sliding friction experiments were conducted with the three as-received amorphous alloys, where norma 1 residual oxides were present on the surface, and in contact with an a luminum oxide ball in argon or in laboratory a ir. Comparative experiments were made with practical materials such as 304 stainless steel foil and $440 \mathrm{C}$ stainless steel. The 304 stainless steel was of equivalent foil thickness as the amorphous alloys. When the amorphous alloys were rubbed by the $6.4 \mathrm{~mm}$-diameter and $3.2 \mathrm{~mm}$-diameter a luminum oxide riders at a load of $2.5 \mathrm{~N}$ (providing contact pressure of approximately 0.8 and $1.3 \mathrm{GPa}$, respectively) for $30 \mathrm{~min}$, essentially no detectable wear existed on the surface of the three amorphous alloys. There was a complete absence of any visible wear track when examined by the optical and scanning electron microscope.

Wear tracks were, however, visible on. the 304 stainless steel foil and the $440 \mathrm{C}$ stainless steel. The wear damage of $440 \mathrm{C}$ stainless steel was much less than that of 304 stainless steel. A copious amount of wea $r$ debris was generated and considerable plastic flow and wear occurred to the 304 sta inless steel surface, and clumps of meta 1 appeared in the wear track [8].

Thus, surface oxide layers present in the amorphous alloys were very effective in providing a protective film aga inst wear.

Since no visible wear was observed on the amorphous alloys, sliding friction experiments were conducted with the $3.2 \mathrm{~mm}-$ diameter a luminum oxide rider at a load of $2.5 \mathrm{~N}$ and with the sliding time extended to $150 \mathrm{hr}$ in order to provide more severe conditions and to remove the protective oxide films.

Figure 4 presents scanning electron micrographs of typical wear tracks on the a morphous a lloy $\mathrm{Fe}_{67} \mathrm{C}_{018} \mathrm{~B}_{14} \mathrm{Si}_{1}$ and the 304 stainless steel foil surfaces at a total sliding time of $5 \mathrm{hr}$. Oxide wear debris particles were generated on the amorphous 
alloy surface, while metal wear debris particles were primarily generated on the stainless steel surface. With the amorphous alloy microscopic brittle fracture and breaking up of oxide layers took place, and fine oxide wear debris particles were ma inly produced. With the 304 stainless steel, however, rupturing the bonds of cohesively weaker 304 stainless steel occurred, cavities were formed in the materia 1, and then sma 11 platelet-type metallic wear debris particles were subsequently produced.

Figure 5 illustrates a detailed examination of the oxide wear debris (submicrons to microns in size) produced on the amorphous a lloy as a result of the sliding action. The scanning electron micrographs clearly revea 1 powdery and whiskery (needle-shaped) oxide wear debris particles on and near the wea $r$ track after sliding contact with the aluminum oxide rider.

Figure $4(a)$ discussed above a lso clearly revea led that plastic flow occurred in the amorphous alloy. The sliding action resulted in plastic deformation not only in the wear track but also at the side of the wear track. Multiple shear deformation bands were observed on the side of the wear track (as shown in Fig. 4(a)). The plastic flow, observed on the side of the wear track, occurs in the form of highly localized shear deformation bands. Thus, a concentration of large shear strains develops in a band during sliding friction process. The shear bands are similar to those in crystalline metals [9]. Figure 6(a) clearly reveals that plastic flow occurs in the wear track of the amorphous a lloy with repeated sliding.

When the aluminum oxide rider in sliding contact with the amorphous alloy was examined by the scanning electron microscope, there were flow films of the alloy adhered and transferred to the aluminum oxide rider surface (as shown in Fig. 6(b)).

During a 150-hr sliding period, considerable plastic flow occurred and considerable oxide debris was generated on the amorphous a 1loy. Figure 7 revea 15 evidence of wear damage and large particles of wear debris, which were generated at local spots. Shear fracture occurs at very local areas in the amorphous alloy during repeated sliding. The wear volume was $0.01 \mathrm{~mm}^{3}$ or less. The wear rate, which is defined as the quantity of amorphous a lloy removed under a unit load and with anjt distance of sliding, was $5 \times 10^{-9} \mathrm{~mm}^{3} / \mathrm{Nmm}$.

\section{Mechanical Effects}

Crystallization of amorphous a lloy in mechanical contact with an aluminum oxide rider ( $3.2 \mathrm{~mm}-$ radius) has been observed to occur during sliding friction with a relatively slow sliding velocity $(1.5 \mathrm{~mm} / \mathrm{sec})$, where in frictional heating is negligible.

A typical example of the wear surface of the $\mathrm{Fe}_{67} \mathrm{C}_{018 \mathrm{~B} 14} \mathrm{Si}$ amorphous a lloy run for $150 \mathrm{hr}$ is shown in Fig. 8. Dark dots and bands, which are believed to be clusters or crystallites ranging in size from 10 to $50 \mathrm{~nm}$, are apparent. Diffused honeycombshaped structures formed by dark grey bands are due to segregation and preferential clustering of transition metals and metalloids. The electron diffraction pattern a lso indicates that the wear surface contained small clusters or gra ins.

Figure 9 presents bright and dark field images and the diffraction pattern of a loca 1 a rea of the wear surface on the amorphous alloy. Dark spots, believed to be clusters or crystallites ranging in size to $150 \mathrm{~nm}$, observed in the bright image are reversed in the dark image. The diffraction pattern was a lso taken from the spots. Figure 9 clearly indicates a partially crystallized phase in the matrix. As seen from these micrographs, star-shaped crystals grow in the Fe67Co18B14Si1 a lloy.

The diffraction pattern includes spotting rings which lose their continuity at $360^{\circ}$ and diffuse ha los. The spotty ring is essentially that for a crystalline material and most of the spot pattern of the crystallized phase was identified as $\alpha-\mathrm{Fe}_{2} \mathrm{O}_{3}$. The diffuse halos indicate that the matrix contains extremely small grains of approximately a few nanometers in size. The results suggest that crystallization may occur by nucleation and growth processes of a-Fe. The dispersed and primary crystallized a-Fe phase may act as the preferred nucleation site for crystallization of the amorphous alloy. The primary crystals, that is, a-Fe may be easily oxidized during sliding friction experiments and transform into $\alpha-\mathrm{Fe}_{2} \mathrm{O}_{3}$.

Thus, a strong interaction between transition metais and metalloids such as boron results in strong segregation and provides preferential transition metalloid clustering $[10,11]$ in the bulk of the amorphous a lloy during the sliding friction process. A highly stra ined amorphous a lloy tends to promote clustering of the amorphous alloy long before the surface may otherwise be ready for such clustering. The extent of segregation of metalloids to clusters and/or crystallites is controlled by strain and this may control the strength of the alloys, as well as friction and wear properties of the a lloys. 


\section{Temperature Effects}

Typical examples of the structure are shown in Fig. 10 for the amorphous alloy foils after heating to $350^{\circ}$ and $430^{\circ} \mathrm{C}$ for 20 min in ultra-high vacuum. The structure of foil heated to $350^{\circ} \mathrm{C}$ is similar to that of the as-received foil a lready shown in Fig. 2. In the structure of the foil that had been heated to $430^{\circ} \mathrm{C}$, which is the socalled crystallization temperature for this particular $\mathrm{Fe}_{6} \mathrm{CO}_{1} \mathrm{~B}_{14} \mathrm{Si}_{1}$ foil, the black spots are stight ly larger than those shown in Figs. 2 and $10(a)$. The diffused honeycomb-shaped structure formed by dark grey bands is enriched and indicates subdivision of amorphous alloy structure as a result of decomposition and separation of amorphous phase. That is, segregation of constituents and preferential clustering are taking place at this temperature. The electron diffraction pattern also indicates the presence of an extra outer ring related to clustering or crystallinity.

Figure 1.1 presents microstructures of the foils heated to $500^{\circ}$ and $750^{\circ} \mathrm{C}$. They revea 1 two $k$ inds of extremely fine-gra ined crystals: a dark grain and a light grain. Energy dispersive $X$-ra $y$ analys is indicated that the 7ight gra ins conta ined about 20 times more silicon than the dark gra ins [3]. The dark grains conta ined more iron and $\mathrm{Fe}-\mathrm{B}$ alloy. The transmission electron diffraction patterns for both the dark and light grains contained diffraction spots and Kikuchi lines indicating single-crystal structure [3]. The crystallized gra in size was $0.7 \mu \mathrm{m}$ a t $500^{\circ} \mathrm{C}$ and to $1.4 \mu \mathrm{m}$ at $750^{\circ} \mathrm{C}$. Thus, the microstructure of the amorphous alloy changes discontinuously and drastically during the amorphous to crystalline transition. The amorphous phase separates into two crysta 1line phases.

Temperature effects lead to drastic changes in surface chemistry of the amorphous: a 1 loys as analyzed by XPS and not only above the crystallization temperature, but below it as well. These changes are dije to segregation and diffusion of constituents, especially of metalloids such as boron and silicon.

A typical example of the XPS spectra of $\mathrm{B}_{1}$ s and $\mathrm{Si}_{2 p}$ peaks obtained on $\mathrm{Fe}_{6} \mathrm{C}_{0} \mathrm{O}_{18} \mathrm{~b}_{14} \mathrm{Si}_{1}$ foil surface is presented in $\mathrm{Fig} .12$.

The $B_{1}$ s photoelectron peaks of the as-received specimen indicate the presence of boric oxide as well as Fe $B$ and $\mathrm{COB}$. The spectrum of the surface that had been argon sputter cleaned for 30 and 60 min revea is large peaks for boron and its alloys as well as very small boric oxide peaks.
The spectra for the foils that had been heated to $750^{\circ} \mathrm{C}$ clearly indicate that the foil surfaces were aga in contaminated with boric oxide at $350^{\circ} \mathrm{C}$ and boron nitride at. $750^{\circ} \mathrm{C}$ that had migrated from the buik of. the foil specimens. The foil-surfaces heated at $500^{\circ} \mathrm{C}$ were a lso contaminated with boron nitride and were the same as that for the heated surface at $750^{\circ} \mathrm{C}$.

The Si2p photoelectron peaks of the a s-received surface reveal silicides. Even the spectrum of the surface that had been a rgon sputter cleaned for $60 \mathrm{~min}$ revea $1 \mathrm{~s}$ silicides as well as silicon oxide on the surface. The foil that had been heated to. $350^{\circ} \mathrm{C}$ was contaminated with silicon oxide that had migrated from the bulk of the foil. ' specimens. The foil heated at $750^{\circ} \mathrm{C}$ contains a small amount of silicon dioxide on the surface compared to that heated at $350^{\circ} \mathrm{C}$

The Fe2p photoelectron peaks of the $\mathrm{Fe}_{67} \mathrm{C}_{18^{\mathrm{B}}} 14^{\mathrm{S}} \mathrm{i}_{1}$ foil hea ted to $350^{\circ}$ and $750^{\circ} \mathrm{C}$ are a lmost the same as that for the argonsputter-cleaned surface shown in Fig.. 3 . The $\mathrm{C}_{2} \mathrm{p}$ photoelectron peaks of the as-received $\mathrm{Fe}_{67} \mathrm{Co}_{18} \mathrm{~B}_{14} \mathrm{Si}_{1}$ foil indicated cobalt oxide. The spectra for the surfaces that had been argon-sputter-cleaned and hea ted to $350^{\circ}$ and $750^{\circ} \mathrm{C}$ revea led cobalt and its alloy peaks. The cobalt oxide peak was negligible [3].

Table III summarizes the surface conditions of the foils analyzed by XPS. Generally, the XPS results indicate that the : surfaces of the as-received foils consisted of a layer of oxides of a lloying elements as well as a simple, adsorbed film of oxygen and carbon. The argon sputter cleaned sur:face consisted of the alloy and small amounts of oxides and carbides. In addition to nominal 1 element constituents, the surface heated to $350^{\circ} \mathrm{C}$ conta ined boric and silicon oxides on $\mathrm{Fe}_{67} \mathrm{CO}_{18} \mathrm{~B}_{14} \mathrm{Si}_{1}$ and $\mathrm{Fe}_{81} \mathrm{~B}_{13} .5^{\mathrm{Si}_{3} .5^{\mathrm{C}} 2}$ a lloys, and boric oxides on $\mathrm{Fe}_{81} \mathrm{Ni}_{38} 8^{\mathrm{Mo}}{ }_{4}^{\mathrm{B}} 18$ alloys as well as sma 11 amounts of carbides that had segregated and migrated from the bulk of the foils. The surface heated to $750^{\circ} \mathrm{C}$ contained boron nitride that had also migrated from the bulk of the foils as well as sma 11 amounts of oxides.

Thus, in situ examinations of the surface chemistry in the heating stage gives valuable information on the behavior of surface segregation and decomposition. The segregation and migration of compounds such as boric oxide and nitride influence the friction behavior of amorphous alloys.

sliding friction experiments were conducted with aluminum oxide in contact with a morphous a lloys in vacuum at temperatures to $750^{\circ} \mathrm{C}$. Friction-force traces resulting 
from such sliding were generally characterized by fluctuating behavior with evidence of stick-slip [3]. The coefficient of friction as a function of the sliding temperature of the foil specimen is indicated in $\mathrm{Fig} .13$. The a luminum oxide rider was sputter cleaned with argon ions at room temperature. The foil specimen was also sputter cleaned with argon ions in the vacuum system and then heated from room tempera ture to $750^{\circ} \mathrm{C}$. The coefficient of friction increased with increasing temperature from room to $350^{\circ} \mathrm{C}$. The increase in friction is due to an increase in the adhesion resulting from segregation of boric oxides and silicon oxides to the foil surface as described earlier. Generally, the presence of oxygen does strengthen the metal-ceramic material (such as $\mathrm{SiC}$ ) contacts and increases the friction [12]. Above $500^{\circ} \mathrm{C}$ the coefficient of friction decreased dramatically. The rapid decrease in friction above $500^{\circ} \mathrm{C}$ correlated with the segregation of boron nitride on the foil surface, as already discussed and shown in Fig. $12(\mathrm{c})$. It is a lso interesting in Fig. 13 that there isla considerable difference in the friction measured for the variations in alloy chemistry.

\section{CONCLUSION}

The following conclusions are drawn from the presented data:

(1) Amorphous a lloys are not completely amorphous, but conta in extremely small clusters or crysta 1lites (nuclei) of approximately a few nanometers (up to $4 \mathrm{~nm}$ ) in size.

(2) Surface oxide layers present on the amorphous alloys are stable and very effective in providing low friction and a protective film a ga inst wear in an air a tmosphere.

(3) Plastic flow occurs on an amorphous alloy surface with sliding. Multiple slip bands due to shear deformation are observed on the sides of the wear track.

(4) Enhanced clustering and crystallizing of amorphous alloys occur during the sliding process at a low sliding velocity where the temperature rise is negligible. Clusters or crystallites with sizes to 150 $\mathrm{nm}$ and diffused honeycomb-shaped structure formed by dark grey bands are produced on the wear surface of the amorphous alloy.

(5) Temperature effects lead to drastic changes in surface chemistry and friction behavior of the amorphous alloys in the range of room temperature to $750^{\circ} \mathrm{C}$. Contaminants can come from the bulk of the material to the surface upon heating and impart to the surface boric oxide and/or silicon oxide at. $350^{\circ} \mathrm{C}$ and boron nitride above $500^{\circ} \mathrm{C}$. The segregation of contaminants is responsible for the friction behavior. The coefficient of friction increases with increasing temperature to $350^{\circ} \mathrm{C}$ in vacuum. The increase in friction is due to an increase in adhesion resulting from surface segregation of boric oxide and/or silicon oxide to the surface of the foil.

Above $500^{\circ} \mathrm{C}$ the coefficient of friction decreased rapidly. The decrease correlates with the segregation of boron nitride to the surface.

(6) The microstructure of amorphous alloy changes discontinuously from the amorphous phase to the multi-crystalline phases during the crystallization process.

\section{REFERENCES}

[1] DeCristofaro, N., and Henschel, C., Weld. J. (Miami), Vol. 5, no. 7, p. 33, (1978)

[2] Miyoshi, K. and Buckley, D. H. "Friction and Surface Chemistry of Some Ferrous-Base'Meta 11 ic Glasses," NASA TP-1991, (1982)

[3] Miyoshi, K. and Buckley, D. H., "Surface Chemistry, Microstructure, and Friction Properties of Some Ferrous-Base Metallic Glasses at Temperatures to $750^{\circ} \mathrm{C}, "$ "NASA TP-2006, (1982)

[4] Miyoshi, K. and Buckley, D. H., "Sliding. Induced Crystalization of Metallic Glass," NASA TP-2140, (1983)

[5] Amuzu, J.K.A., J. Phys. D, Vol.: 13, p. $L 127(1980)$

[6] Zum Gahr, K. H. and Nöcker, H., Méta 11. (Berlin), Vol. 35, No. 10 p. 988, (1980)

[7] Ozawa, K., Wakasugi, H. and Tanaka, K., IEEE Transactions on Magnetics, Vol. Mag.-20, No. 2, p. 425, (1984)

[8] Miyoshi, K. and Buckley, 0. H.:, "Friction and Wear of Some Ferrous-Base Meta 11 ic Glasses," ASLE Preprint No. 83-LC-5A3, (1983); NASA TM-83067, (1983)

[9] Barquins, M., Kenne], M. and Courtel, R., Wear, Vol. 11, p. 87, (1968)

[10] Köster, U. and Herold, U., "Glassy Metals I," edited by H. J. Güntherodt and $H$. Beck, Springer-Verlag, P. 225, (1981)

[11] Polk, D. E. and Giessen, B. C. Metallic Glasess, American Society for Meta.1s, p. 1, (1978)

[12] Miyoshi, K. and Buckley, D. H., "Effect of Oxygen and Nitrogen Interactions on Friction of Single-Crystal Silicon Carbide," NASA TP-1265 (1978) 
TABLE I - - PROPERTIES OF METALLIC GLASSES

\begin{tabular}{|c|c|c|c|c|c|}
\hline $\begin{array}{c}\text { Nominal } \\
\text { alloy } \\
\text { composition, } \\
\text { wt } \%\end{array}$ & $\begin{array}{c}\text { Crystallization } \\
\text { temperature, } \\
\text { C }\end{array}$ & $\begin{array}{c}\text { Density, } \\
g / \mathrm{cm}^{3}\end{array}$ & $\begin{array}{c}\text { Hardness, } \\
\text { GPa }\end{array}$ & $\begin{array}{c}\text { Ultimate } \\
\text { tensile } \\
\text { strength, } \\
\text { GPa }\end{array}$ & $\begin{array}{c}\text { Bend } \\
\text { ductility, } \\
\varepsilon\end{array}$ \\
\hline $\mathrm{Fe}_{67} \mathrm{Co}_{18} \mathrm{~B}_{14} \mathrm{Si}_{1}$ & 430 & 7.56 & 10 & 1.5 & 1 \\
$\mathrm{Fe}_{81^{\mathrm{B}} 13.5^{\mathrm{Si}} 3.5_{2}}$ & 480 & 7.3 & 10.3 & 0.7 & $9 \times 10^{-3}$ \\
$\mathrm{Fe}_{40} \mathrm{Ni}_{38} \mathrm{Mo}_{4} \mathrm{~B}_{18}$ & 410 & 8.02 & 10.5 & 1.38 & 1 \\
\hline
\end{tabular}

$a_{\varepsilon=t}(d-t)$, where $t$ is ribbon thickness and $d$ is micrometer spacing at bend fracture.

TABLE II - - COMPOSITION OF ARGON-SPUTTER-CLEANED SURFACE LAYER OF AMORPHOUS ALLOYS

\begin{tabular}{|c|c|c|}
\hline Nomina 1 bulk & composition & Composition on surface, \\
\hline wt $\$$ a & at. $\%$ & at. $q b$ \\
\hline 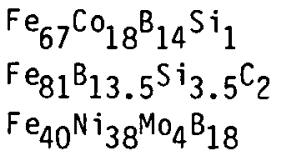 & $\begin{array}{l}\mathrm{Fe}_{42}{ }^{\mathrm{Co}}{ }_{11} \mathrm{~B}_{46} \mathrm{Si}_{1} \\
\mathrm{Fe}_{48} \mathrm{~B}_{42} \mathrm{Si}_{4} \mathrm{C}_{6} \\
\mathrm{Fe}_{23} \mathrm{Ni}_{21} \mathrm{Mo}_{1} \mathrm{~B}_{55}\end{array}$ & $\begin{array}{l}\mathrm{Fe}_{49}{ }^{\mathrm{Co}}{ }_{14} \mathrm{~B}_{17} \mathrm{Si}_{6} \mathrm{C}_{9} \mathrm{O}_{5} \\
\mathrm{Fe}_{43^{\mathrm{B}}}{ }_{15^{\mathrm{Si}}} \mathrm{i}_{8} \mathrm{C}_{21} \mathrm{O}_{14} \\
\mathrm{Fe}_{18^{\mathrm{Ni}}}{ }_{28} \mathrm{Mo}_{1} \mathrm{~B}_{24} \mathrm{C}_{15^{\circ} \mathrm{O}_{14}}\end{array}$ \\
\hline
\end{tabular}

\footnotetext{
aManufacturer's analysis.

Relative concentrations of the various constituents were determined using peak area sensitivity factors and peak area.
} 
TABLE III. - SURFACE OF AMORPHOUS ALLOYS

\begin{tabular}{|c|c|c|c|c|}
\hline \multirow{2}{*}{$\begin{array}{l}\text { Alloy } \\
\text { composition }\end{array}$} & \multicolumn{4}{|c|}{ Surface } \\
\hline & As received & $\begin{array}{l}\text { Argon sputter } \\
\text { cleaned }\end{array}$ & Hea ted to $350^{\circ} \mathrm{C}$ & Heated to $750^{\circ} \mathrm{C}$ \\
\hline Fe67Co18B14Sil & $\begin{array}{l}\text { Oxides of Fe, } \\
\text { Co, B, Si, } \\
\text { and C } \\
\text { Adsorbed film } \\
\text { of oxygen } \\
\text { and carbon }\end{array}$ & $\begin{array}{l}\text { Alloy } \\
\text { Sma } 11 \text { a mount } \\
\text { of oxides } \\
\text { and carbides }\end{array}$ & $\begin{array}{l}\text { Alloy } \\
\text { Boric oxides and } \\
\text { silicon oxides } \\
\text { migrated from } \\
\text { bulk } \\
\text { Sma } 11 \text { amount of } \\
\text { carbides }\end{array}$ & $\begin{array}{l}\text { Alloy } \\
\text { Boron nitride } \\
\text { migrated from } \\
\text { bulk } \\
\text { Very sma } 11 \text { amount } \\
\text { of boric oxides } \\
\text { and silicon } \\
\text { oxides }\end{array}$ \\
\hline $\mathrm{Fe}_{81^{\mathrm{B}}} 13.5^{\mathrm{Si}} 3.5^{\mathrm{C}} 2$ & $\begin{array}{l}\text { 0xides of } \mathrm{Fe} \text {, } \\
\text { B, Si, and } \mathrm{S} \\
\text { Adsorbed film } \\
\text { of oxygen } \\
\text { and carbon }\end{array}$ & $\begin{array}{l}\text { Alloy } \\
\text { Sma } 11 \text { amount } \\
\text { of oxides } \\
\text { and carbides }\end{array}$ & $\begin{array}{l}\text { Alloy } \\
\text { Boric oxides and } \\
\text { silicon oxides } \\
\text { migrated from } \\
\text { bulk } \\
\text { Sma } 11 \text { amount of } \\
\text { carbides }\end{array}$ & $\begin{array}{l}\text { Alloy } \\
\text { Boron nitride } \\
\text { migrated from } \\
\text { bulk } \\
\text { Very sma } 11 \text { amount } \\
\text { of boric oxides } \\
\text { and silicon } \\
\text { oxides }\end{array}$ \\
\hline $\mathrm{Fe}_{4} 0^{\mathrm{Ni}} 38^{\mathrm{Mo}_{4} \mathrm{~B}} 18$ & $\begin{array}{l}\text { Oxides of } \mathrm{Fe} \text {, } \\
\mathrm{B}, \mathrm{Ni}, \mathrm{Mo}, \\
\text { and } \mathrm{B} \\
\text { Adsorbed film } \\
\text { of oxygen } \\
\text { and carbon }\end{array}$ & $\begin{array}{l}\text { Alloy } \\
\text { Sma } 11 \text { amount } \\
\text { of oxides } \\
\text { and carbides }\end{array}$ & $\begin{array}{l}\text { Alloy } \\
\text { Boric oxides } \\
\text { migrated from } \\
\text { bulk } \\
\text { Sma } 11 \text { amount of } \\
\text { carbides }\end{array}$ & $\begin{array}{l}\text { Alloy } \\
\text { Boron nitride } \\
\text { migrated from } \\
\text { bulk } \\
\text { Very sma } 11 \text { amount } \\
\text { of boric oxides }\end{array}$ \\
\hline
\end{tabular}




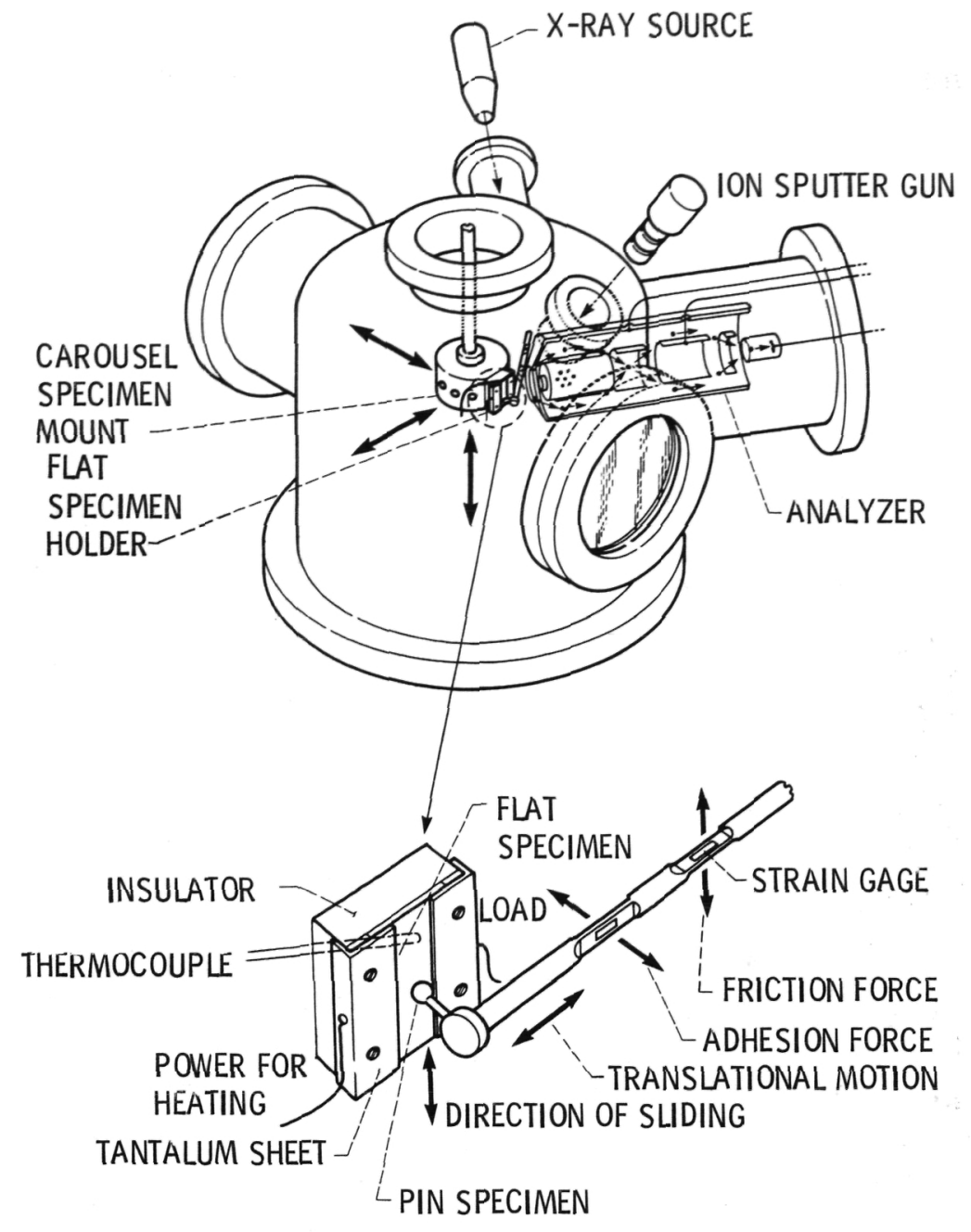

(a) Ultra high-vacuum friction and wear apparatus.

Figure 1. - Friction and wear apparatuses.

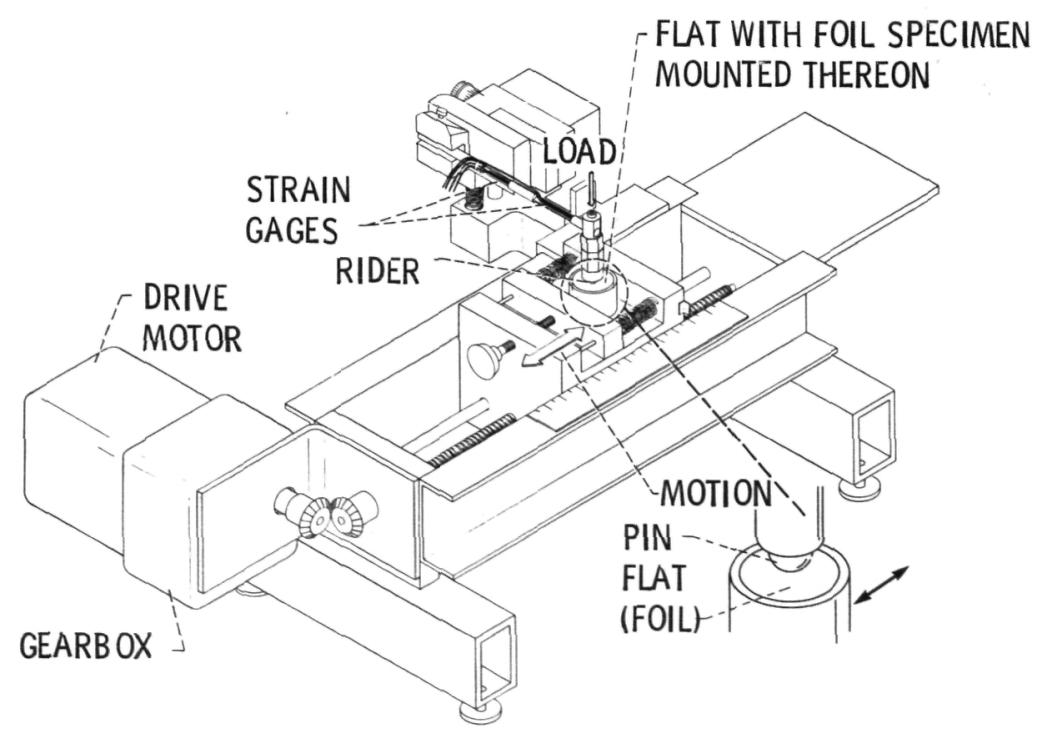

(b) Friction and wear apparatus u sed in argon and in laboratory air.

Figure 1. - Concluded. 


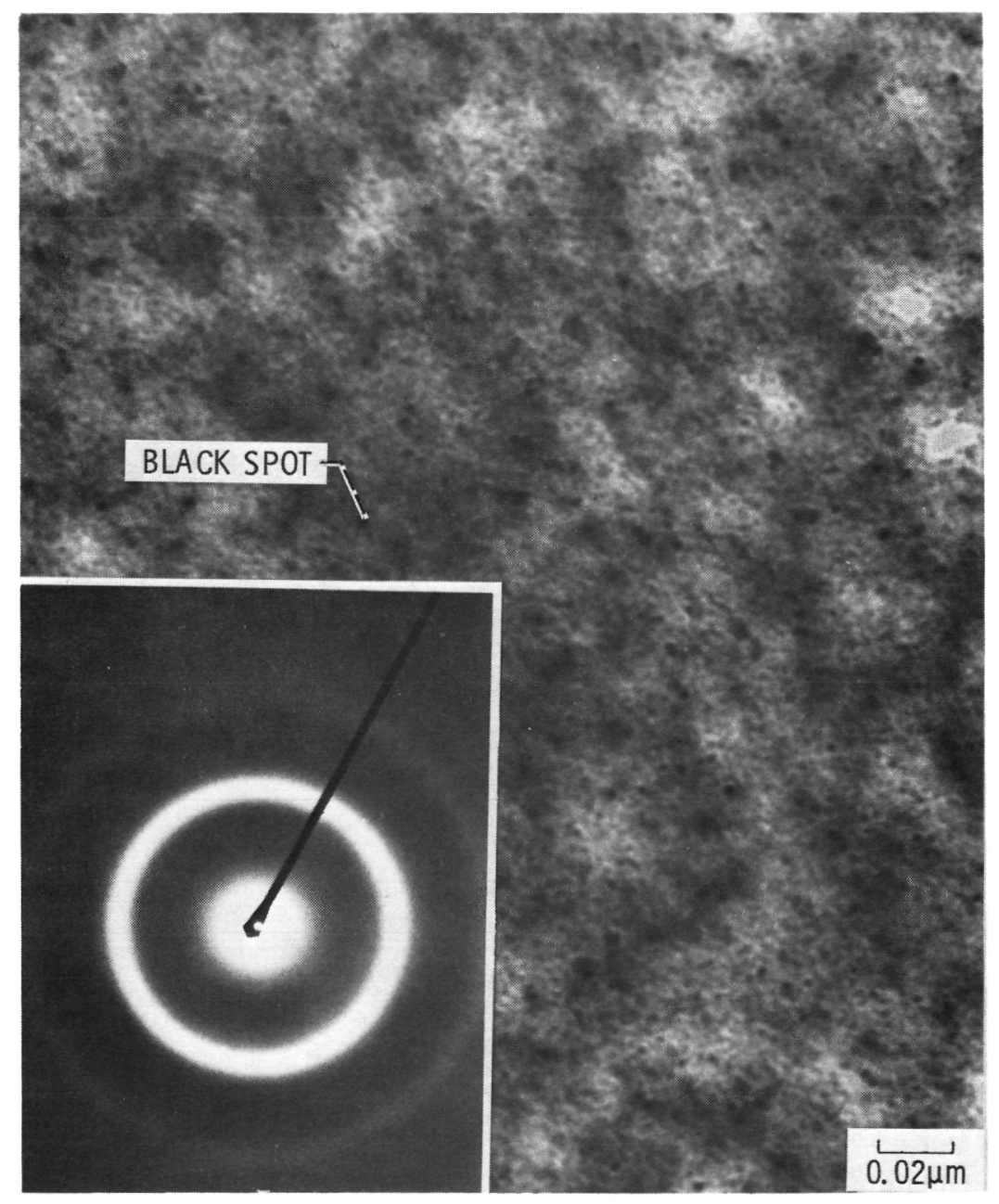

Figure 2. - Typical microstructure and electron diffraction pattern of an amorphous alloy $\left(\mathrm{Fe}_{67} \mathrm{Co}_{18} \mathrm{~B}_{14} \mathrm{Si}_{1}\right)$. 


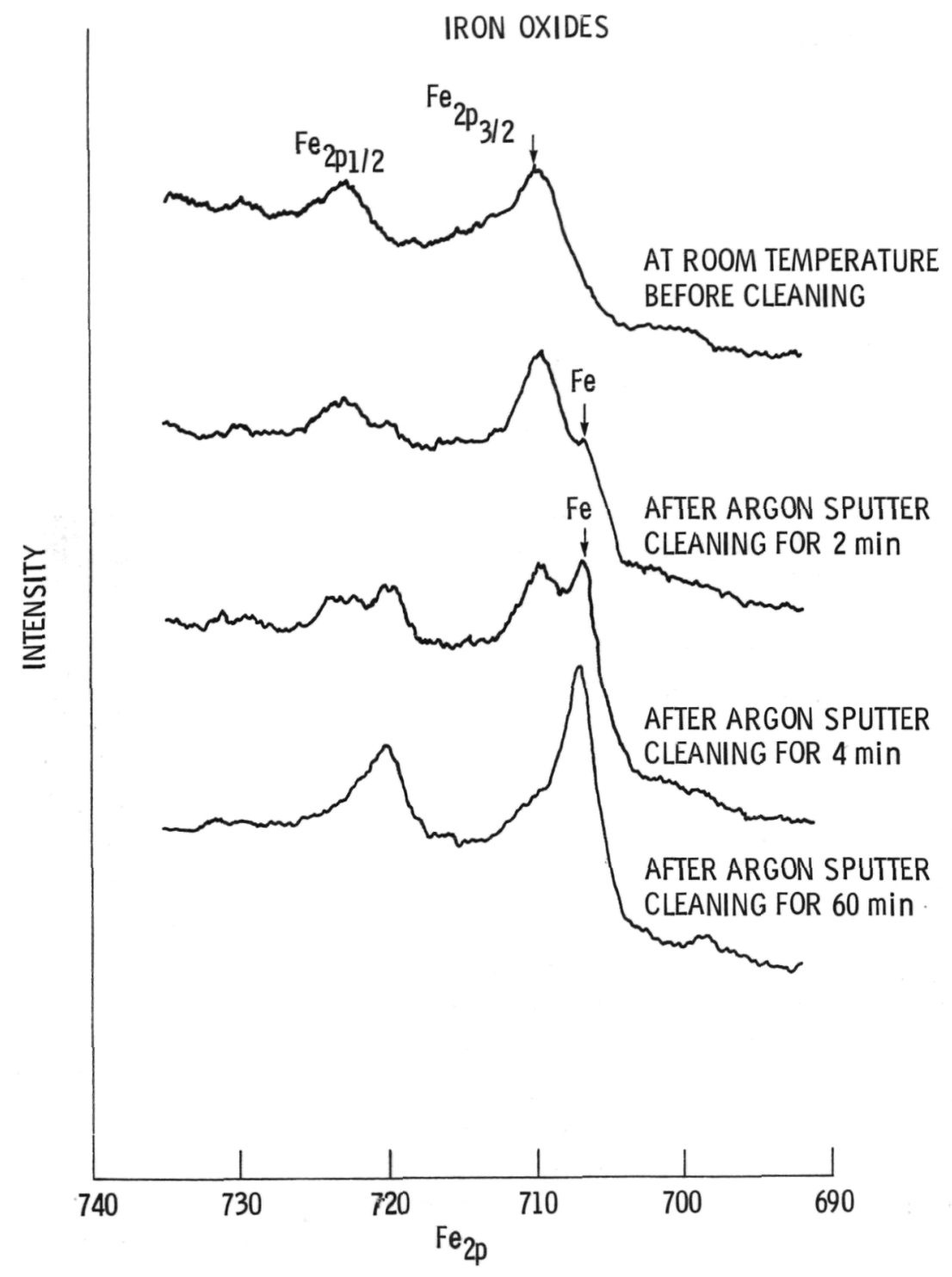

Figure 3. $-\mathrm{Fe}_{2 p}$ XPS peaks on $\mathrm{Fe}_{67} \mathrm{C}_{18} \mathrm{~B}_{14} \mathrm{Si}_{1}$ surface. 

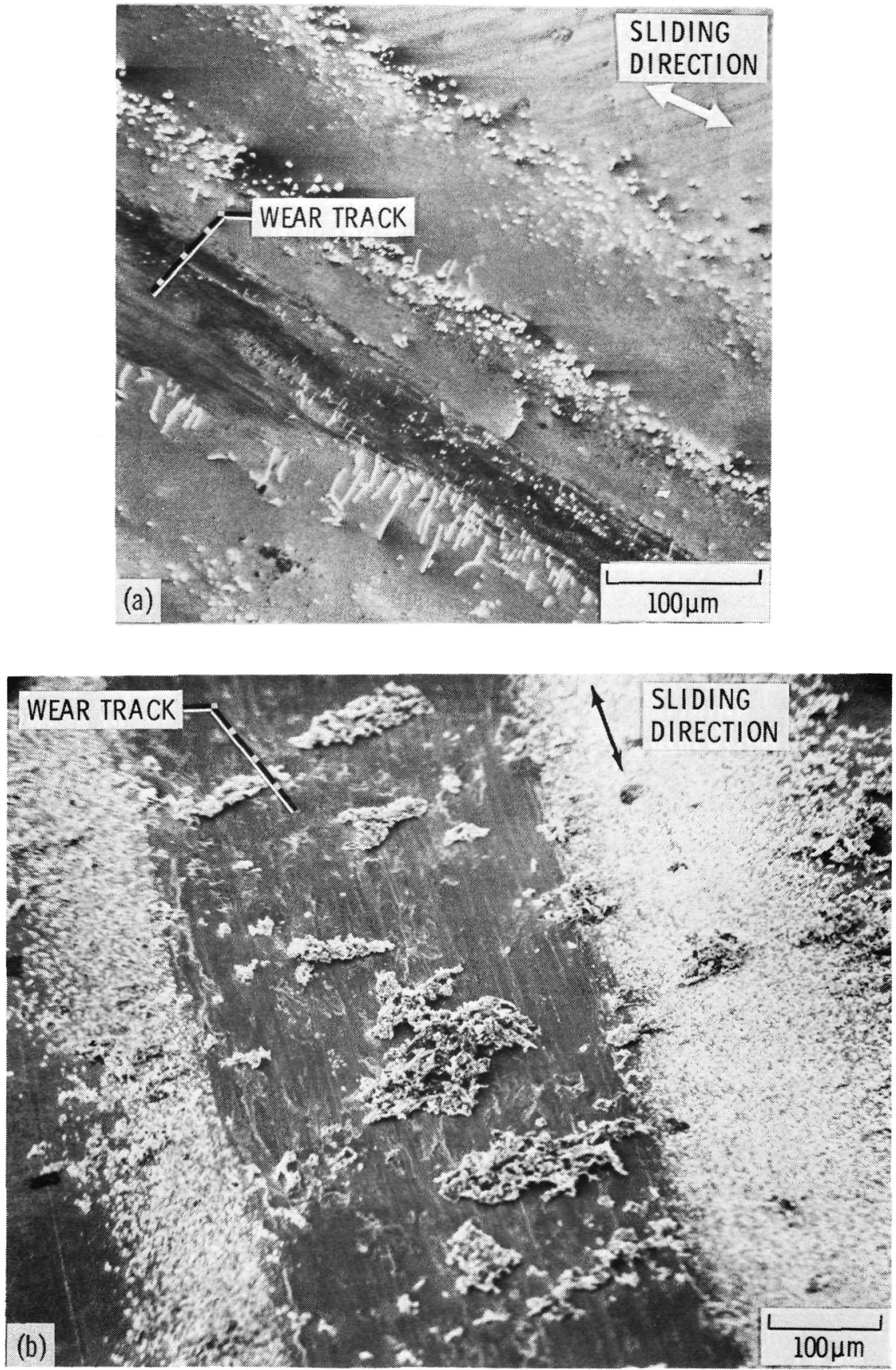

(a) $\mathrm{Fe}_{67} \mathrm{CO}_{18} \mathrm{~B}_{14} \mathrm{Si}_{1}$.

(b) 304 stainless steel.

Figure 4. - Scanning electron micrographs of wear track on $\mathrm{Fe}_{67} \mathrm{CO}_{18} \mathrm{~B}_{14} \mathrm{Si}_{1}$ amorphous alloy and wear track on 304 stainless steel. Pin, 3.2 millimeters diameter aluminum oxide sphere; load, 2.5 newtons; sliding velocity, 1.5 millimeters per second; sliding distance, 27 meters; room temperature; laboratory air atmosphere; relative humidity, $40 \%$. 

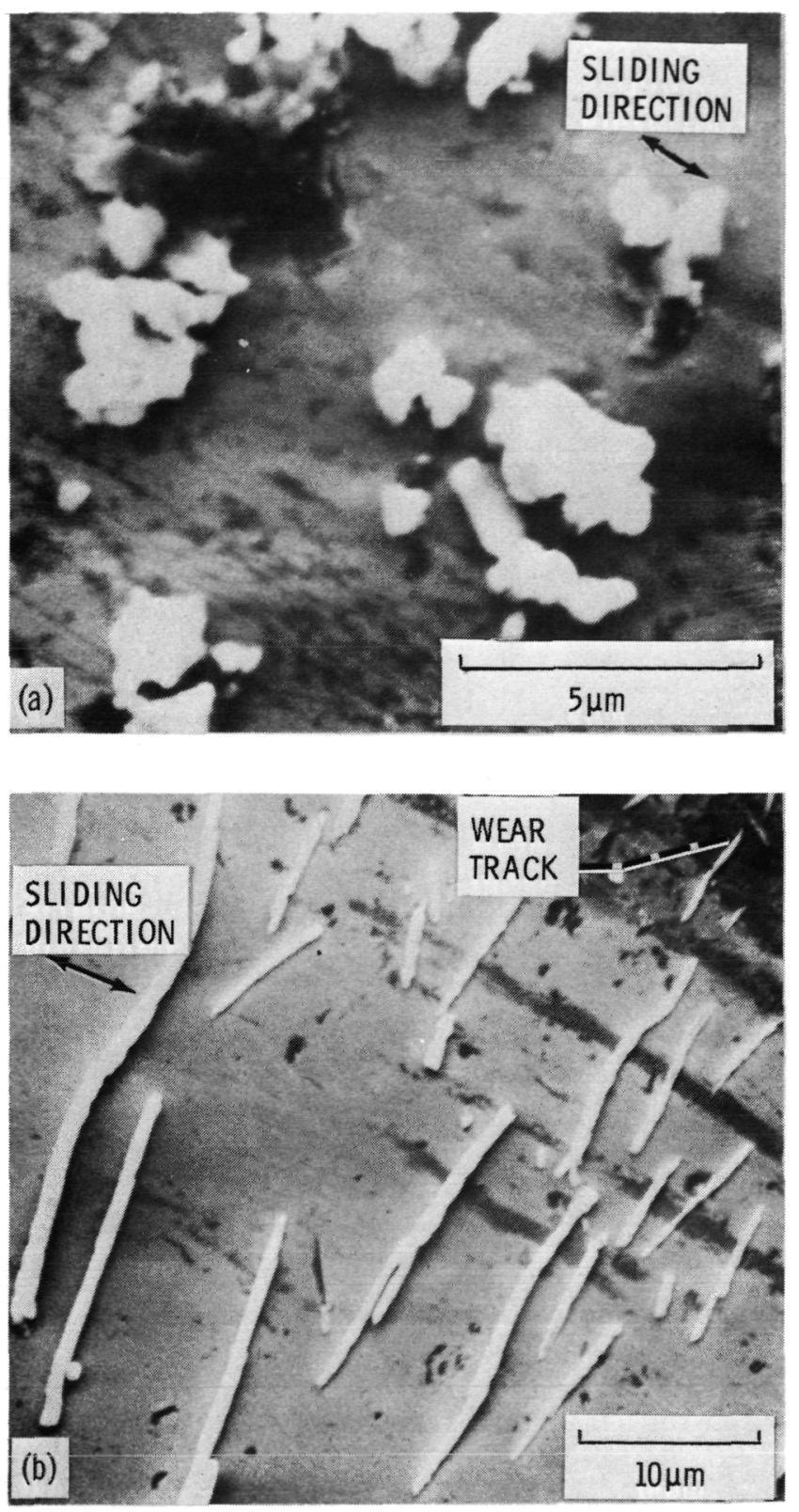

(a) Powdery debris on the wear track.

(b) Whiskery debris on the side of wear track.

Figure 5. - Scanning electron micrographs of powdery and whiskery wear debris particles produced on $\mathrm{Fe}_{67} \mathrm{CO}_{18}$ $\mathrm{B}_{14} \mathrm{Si}_{1}$ amorphous alloy. Pin, 3.2 mi lli meters diameter aluminum oxide sphere; sliding velocity, 1.5 millimeters per second; load, 2.5 newtons; sliding distance, 27 meters; room temperature; laboratory air atmosphere; relative humidity, $40 \%$. 


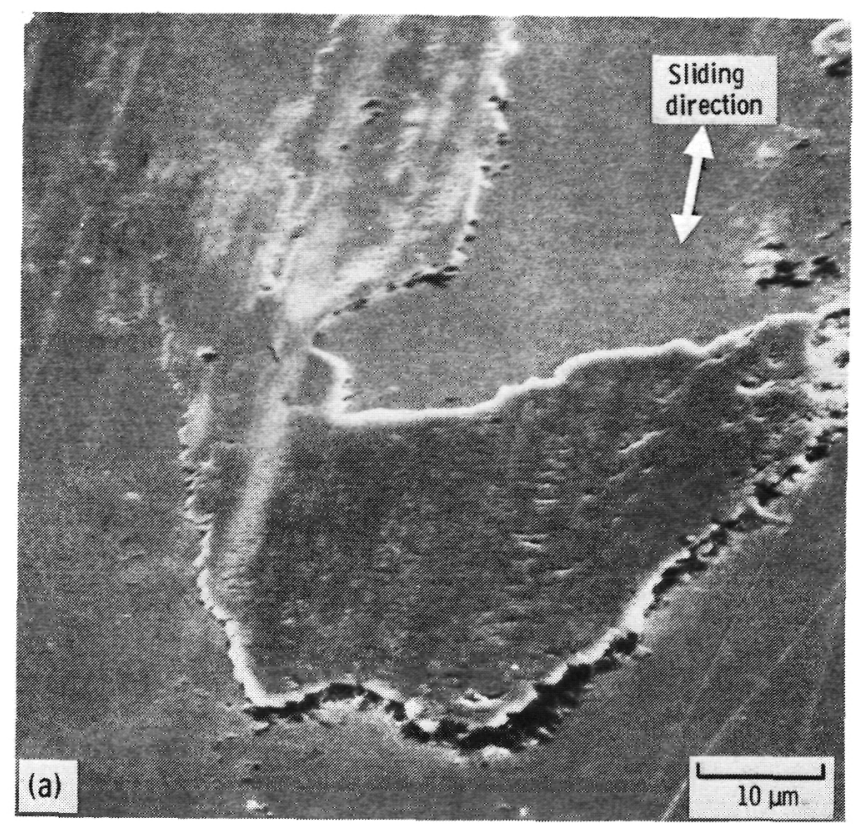

(a) Wear track.

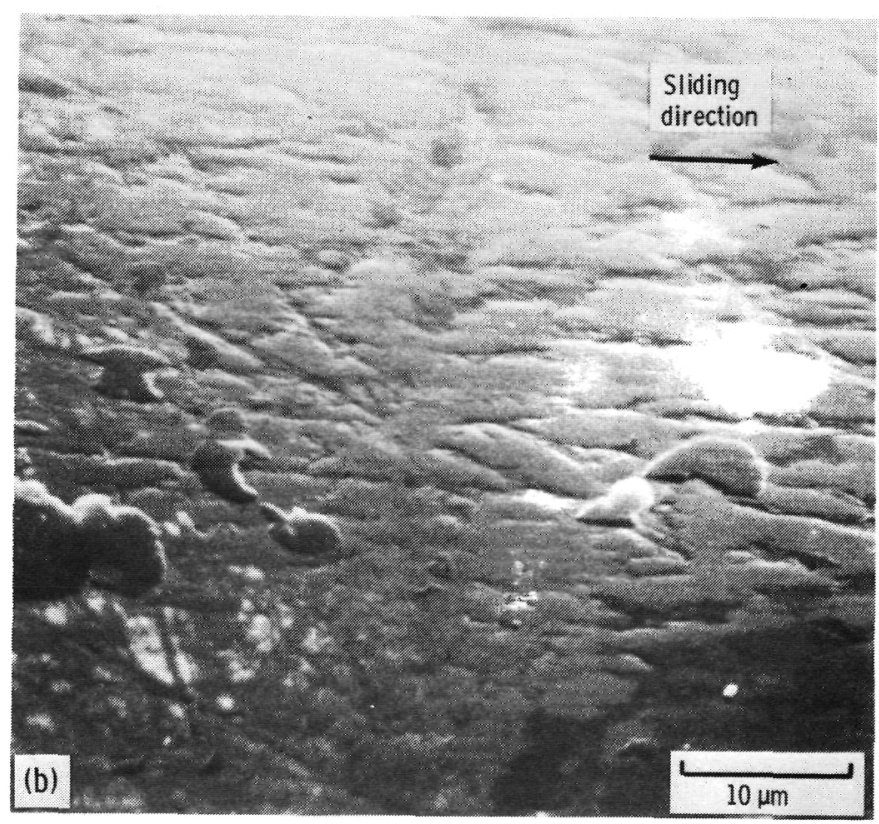

(b) Wear scar.

Figure 6. - Scanning electron micrographs of wear track on $\mathrm{Fe}_{67} \mathrm{CO}_{18} \mathrm{~B}{ }_{14} \mathrm{Si}_{1}$ amorphous alloy and wear scar on aluminum oxide rider sliding on $\mathrm{Fe}_{67} \mathrm{CO}_{18} \mathrm{~B}_{14} \mathrm{Si}_{1}$ amorphous alloy surface. Rider, 3.2-mi llimeter-diameter aluminum oxide sphere; load, 2.5 newtons; sliding velocity, 1.5 millimeters per second; sliding ti me, 5 hours; sliding distance, 27 meters; room temperature; laboratory air atmosphere. 


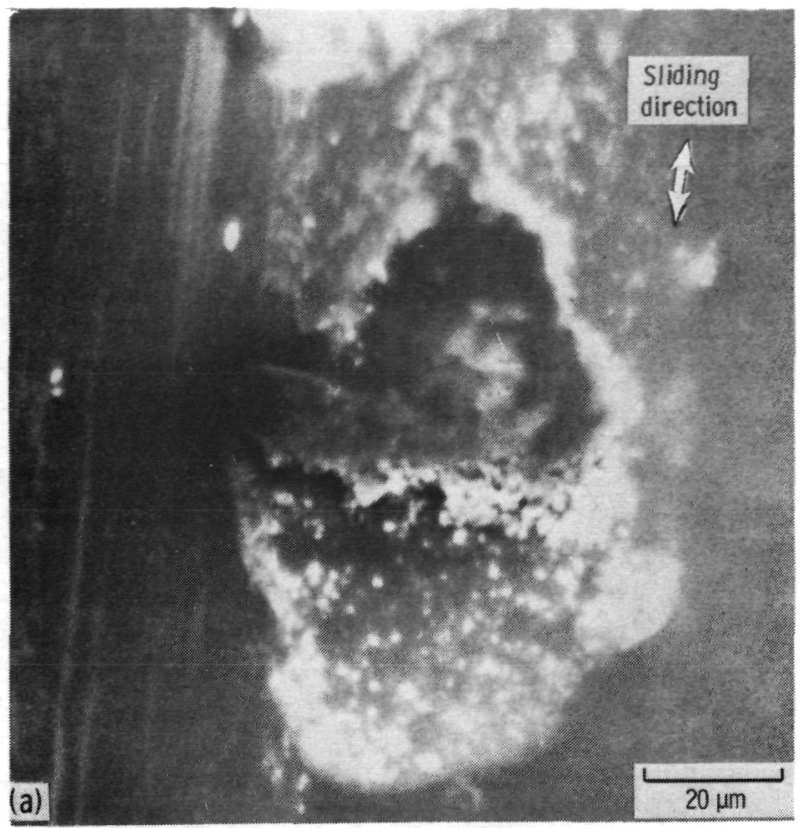

(a) Wear damage.

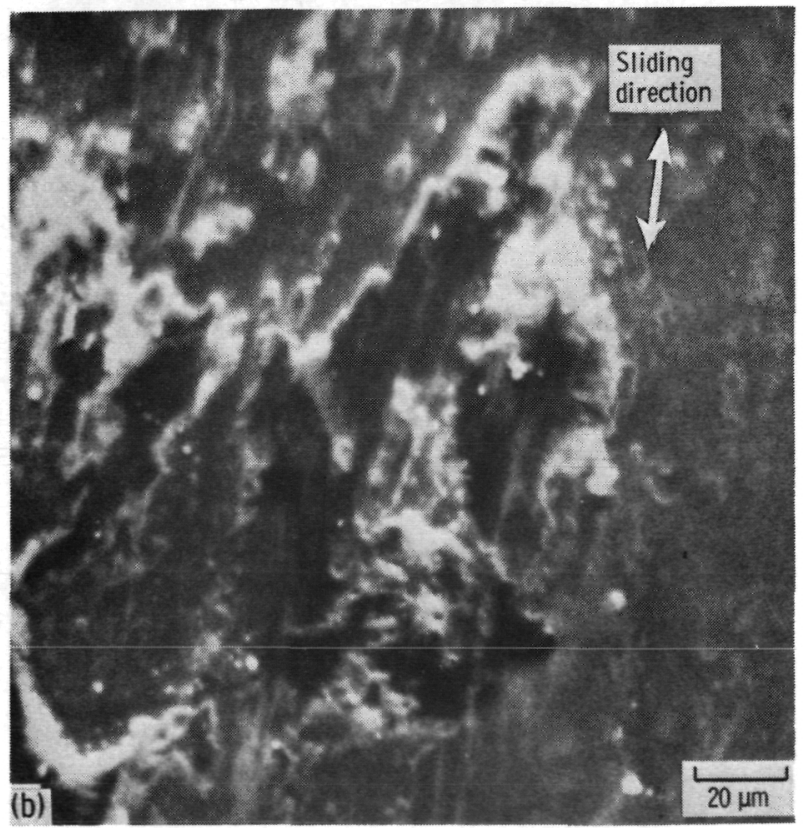

(b) Back-transferred wear debris.

Figure 7. - Scanning electron micrographs of wear track on $\mathrm{Fe}_{67} \mathrm{CO}_{18} \mathrm{~B} 14 \mathrm{Si}_{1}$ amorphous alloy at sliding period of 150 hours. Rider, 3. 2-millimeter-diameter aluminum oxide sphere ; load, 2.5 newtons; sliding velocity, 1.5 millimeters per second; sliding time, 150 hours; sliding distance, 810 meters; room temperature; laboratory air atmosphere. 


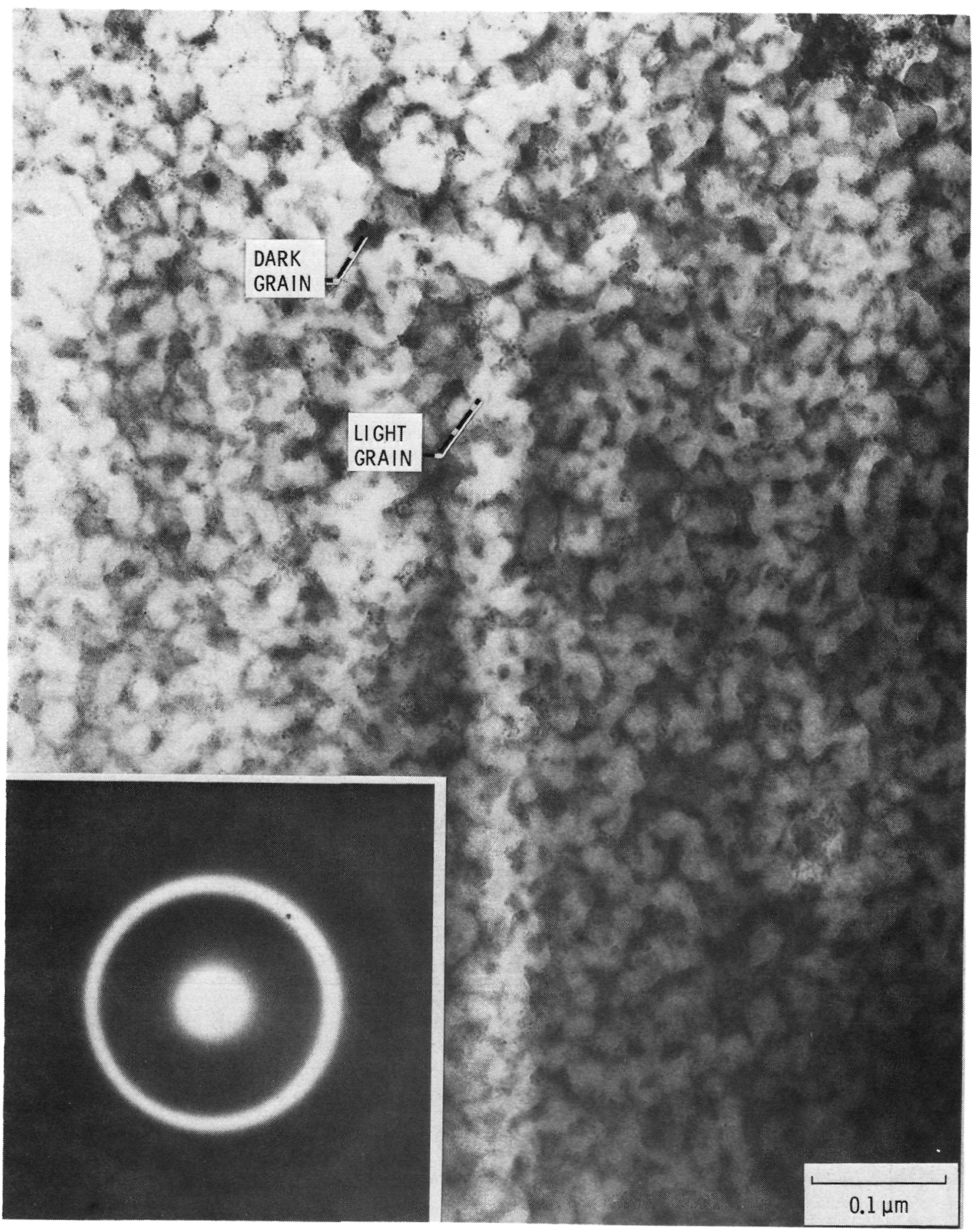

Figure 8. - Typical microstructure and electron diffraction patterns of wear surface of metallic glass $\left(\mathrm{Fe}_{67}\right.$ $\mathrm{CO}_{18} \mathrm{~B}_{14} \mathrm{Si} \mathrm{l}_{1}$ ). Rider, 3.2 - millimeter-diameter aluminum oxide sphere; load, 2.5 newtons; sliding velocity, 1.5 millimeters per second; sliding time, 150 hours; sliding distance, 810 meters; room temperature; laboratory air atmosphere. 


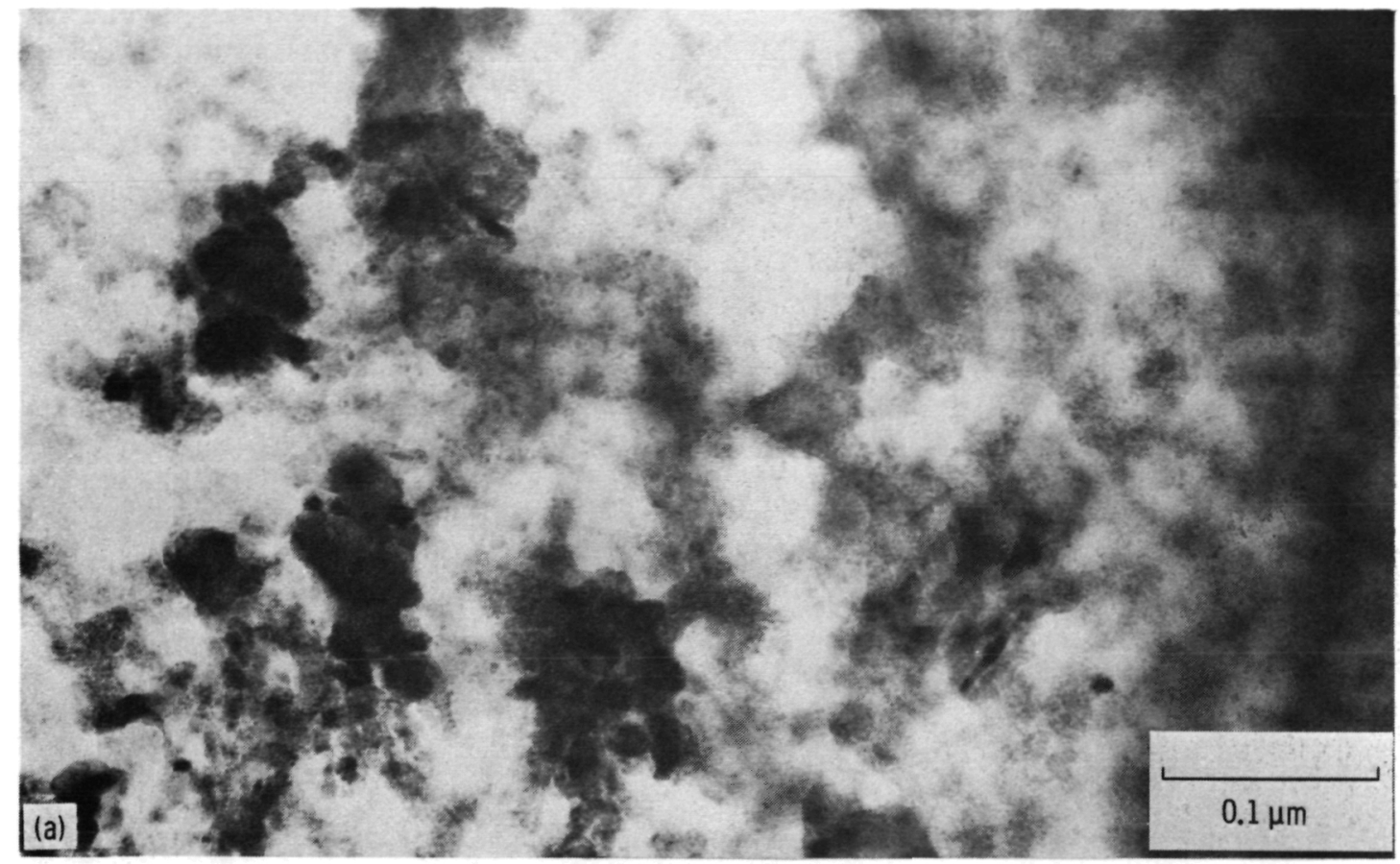

(a) Bright field.

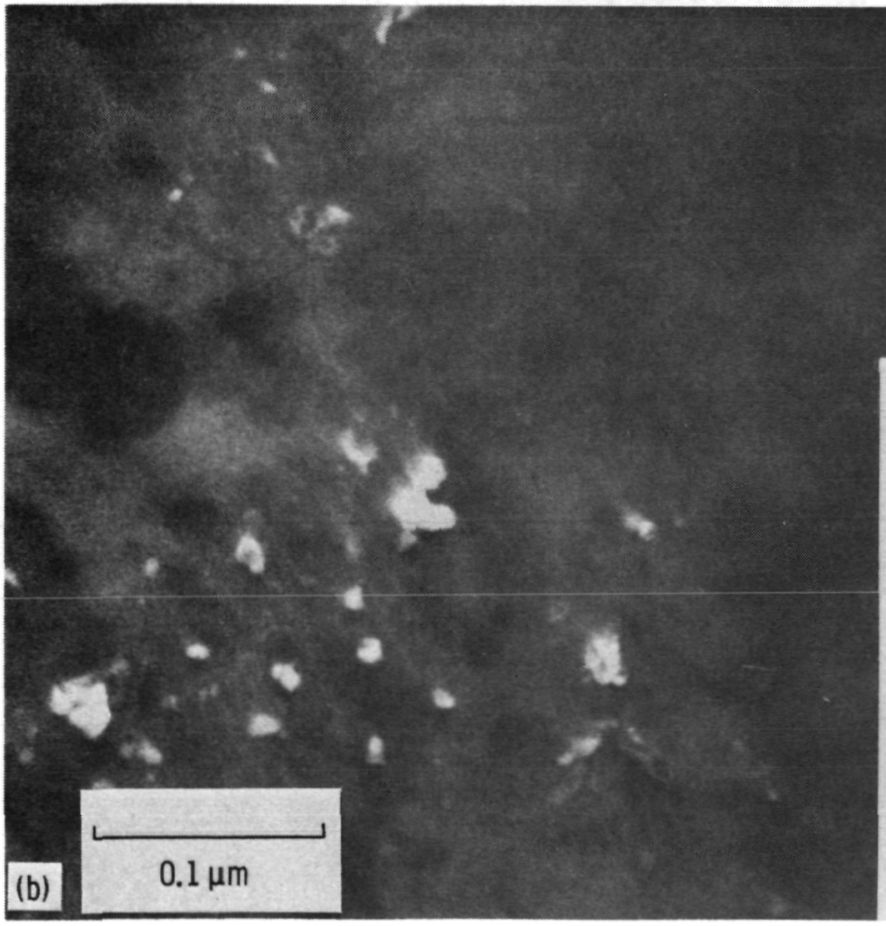

(b) Dark field.

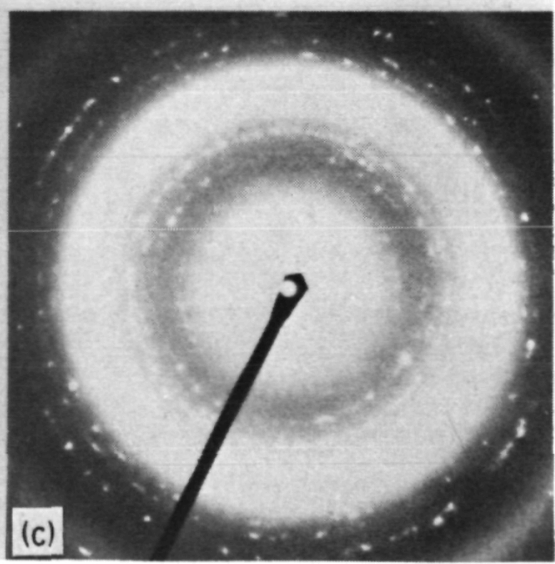

(c) Diffraction pattern.

Figure 9. - Microstructure and electron diffraction patterns of wear surface of metallic glass $\left(\mathrm{Fe}_{67} \mathrm{Co}_{18}{ }^{\mathrm{B}} 14\right.$ $\mathrm{Si}_{1}$ ). Rider, 3.2-millimeter-diameter aluminum oxide sphere; load, 2.5 newtons; sliding velocity, 1.5 milli meters per second; sliding ti me, 150 hours; sliding distance, 810 meters; room temperature; laboratory air atmosphere. 

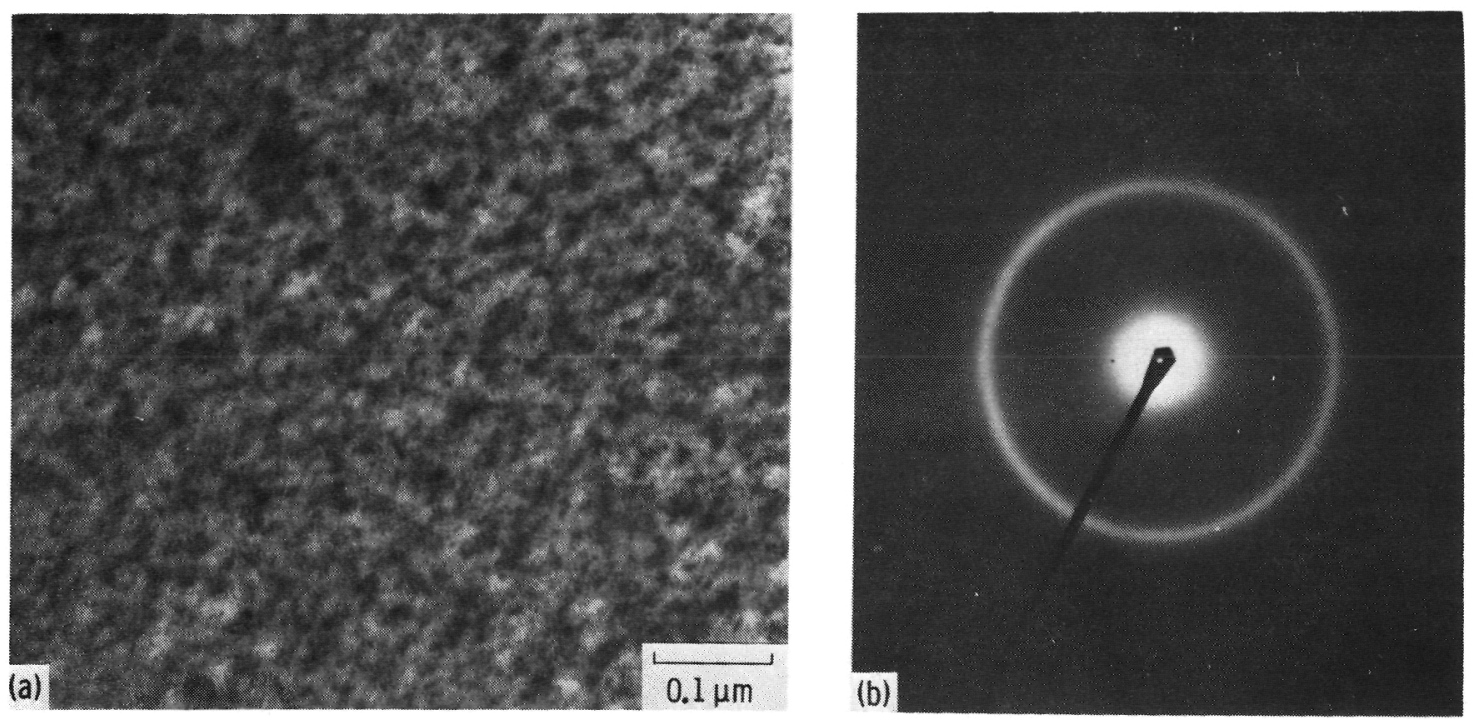

Metallic glass heated to $350^{\circ} \mathrm{C}$ : (a) microstructure and (b) diffraction pattern.
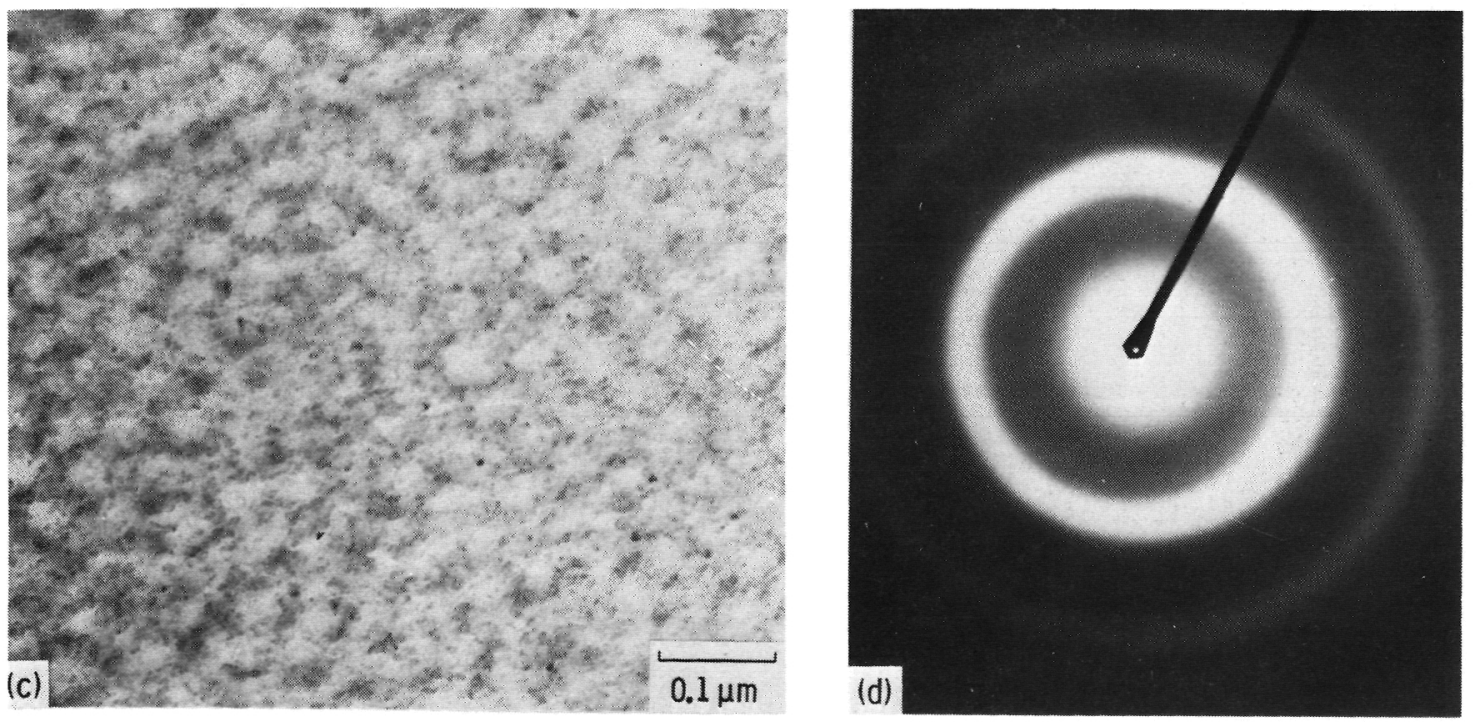

Metallic glass heated to $430^{\circ} \mathrm{C}$ : (c) microstructure and (d) diffraction pattern.

Figure 10. - Microstructure and electron diffraction pattern of an amorphous alloy $\left(\mathrm{Fe}_{67} \mathrm{CO}_{18} \mathrm{~B} 14^{\mathrm{Si}}\right)_{1}$ ) heated to $350^{\circ} \mathrm{C}$ and $430^{\circ} \mathrm{C}$ in vacuum ( $\left.10 \mathrm{nPa}\right)$. 

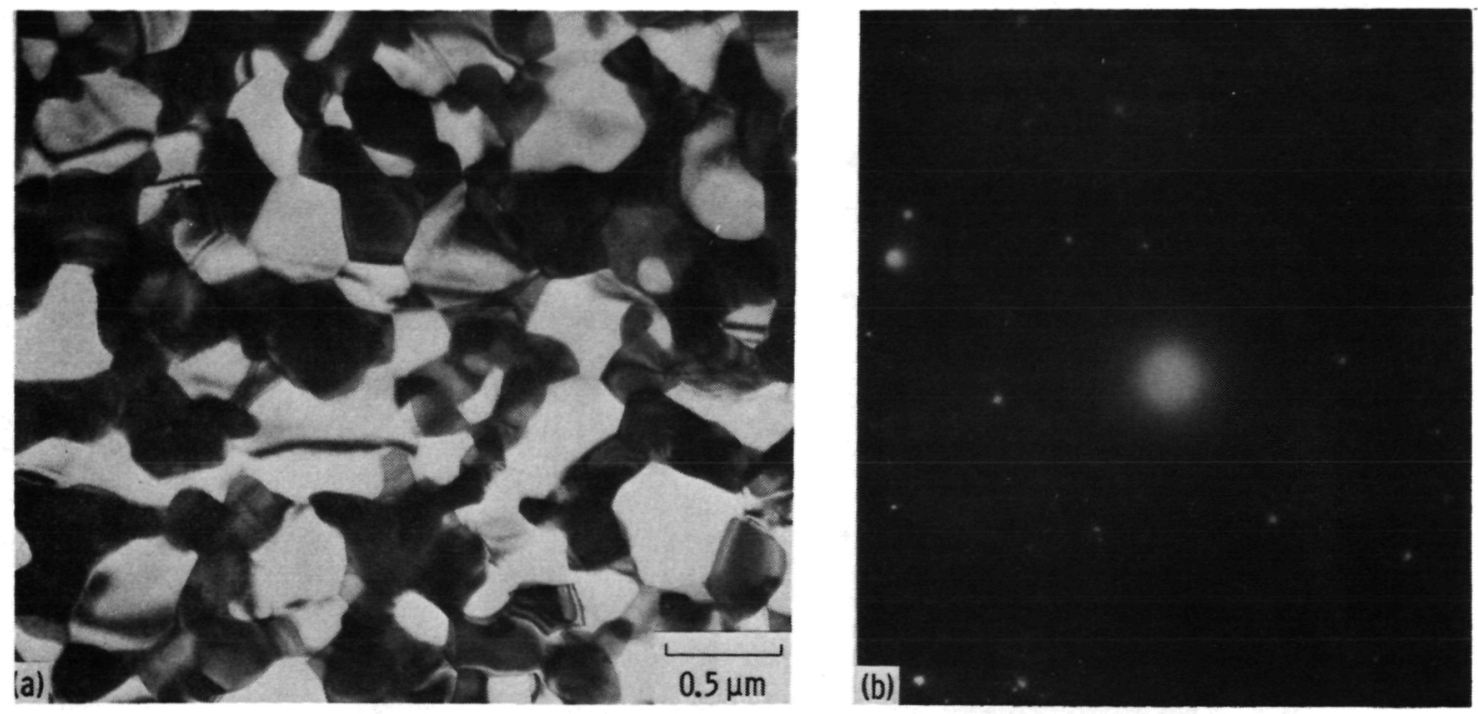

Metallic glass heated to $500^{\circ} \mathrm{C}$ : (a) microstructure and (b) diffraction pattern.
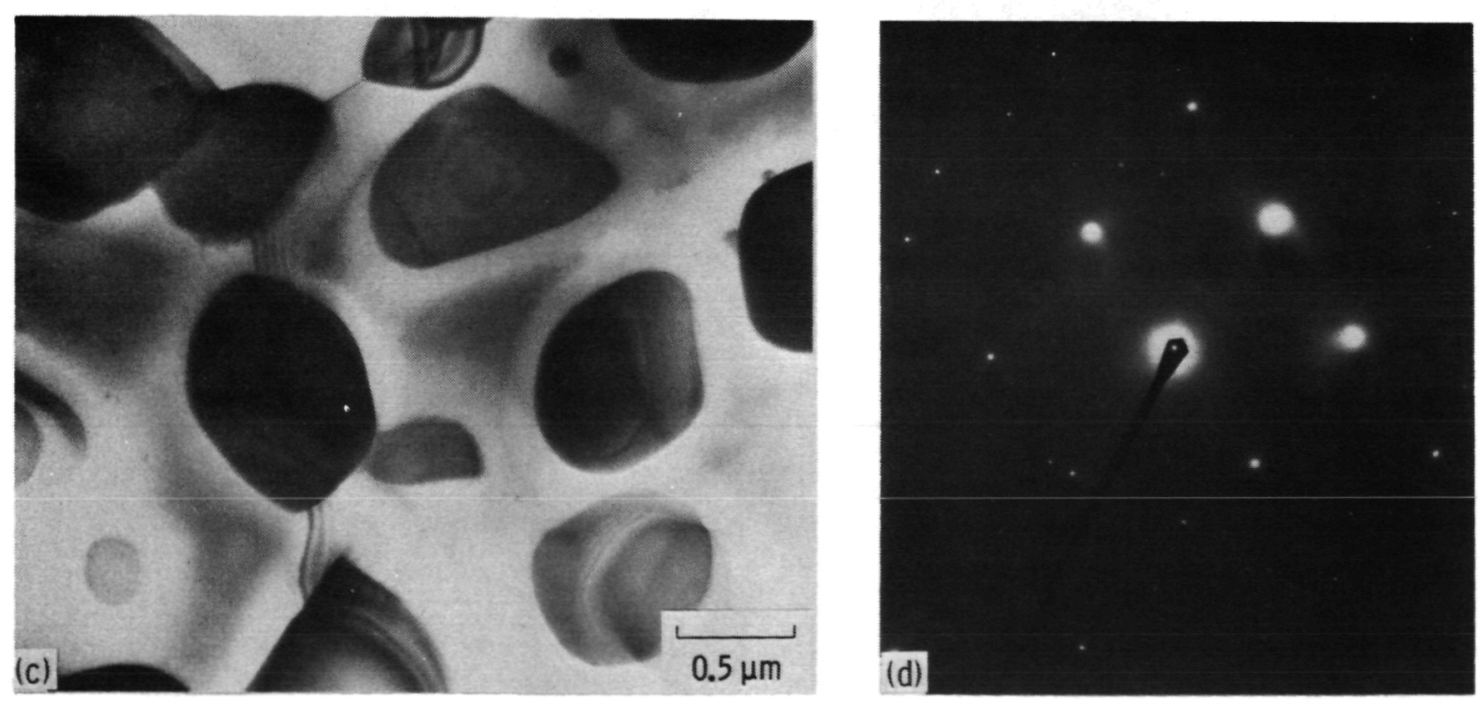

Metallic glass heated to $750^{\circ} \mathrm{C}$ : (c) microstructure and (d) diffraction pattern.

Figure 11. - Microstructure and electron diffraction pattern of an amorphous alloy $\left(\mathrm{Fe}_{67} \mathrm{C}_{18} \mathrm{~B}_{14} \mathrm{Si}_{1}\right)$ heated to $500^{\circ} \mathrm{C}$ and $750^{\circ} \mathrm{C}$ in vacuu $\mathrm{m}(10 \mathrm{nPa})$. 

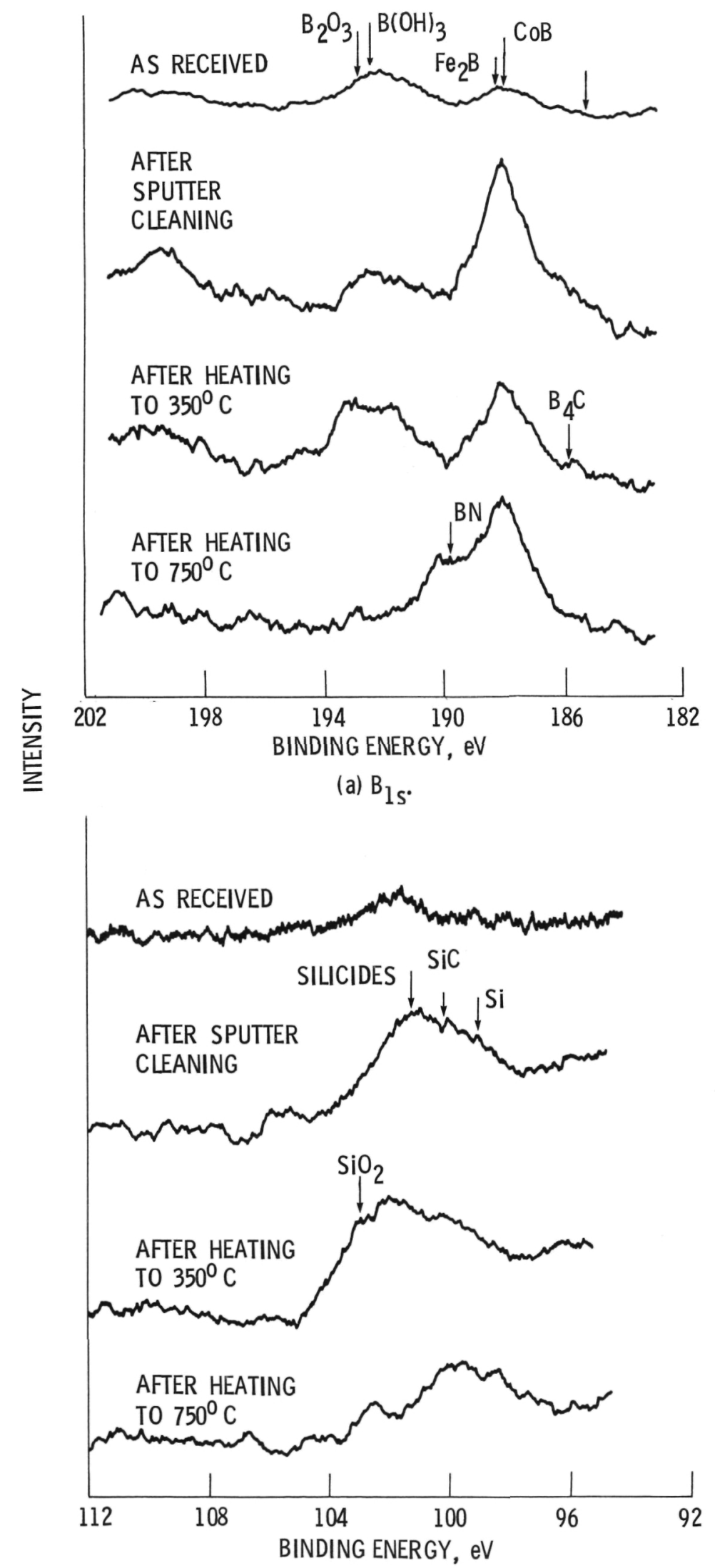

(b) $\mathrm{Si}_{2 p}$

Figure 12. - Representative $\mathrm{B}_{1 \mathrm{~s}}$ and $\mathrm{Si}_{2 \mathrm{p}}$ XPS peaks on $\mathrm{Fe}_{67} \mathrm{C}_{18} \mathrm{~B}_{14} \mathrm{Si}_{1}$ surface. 


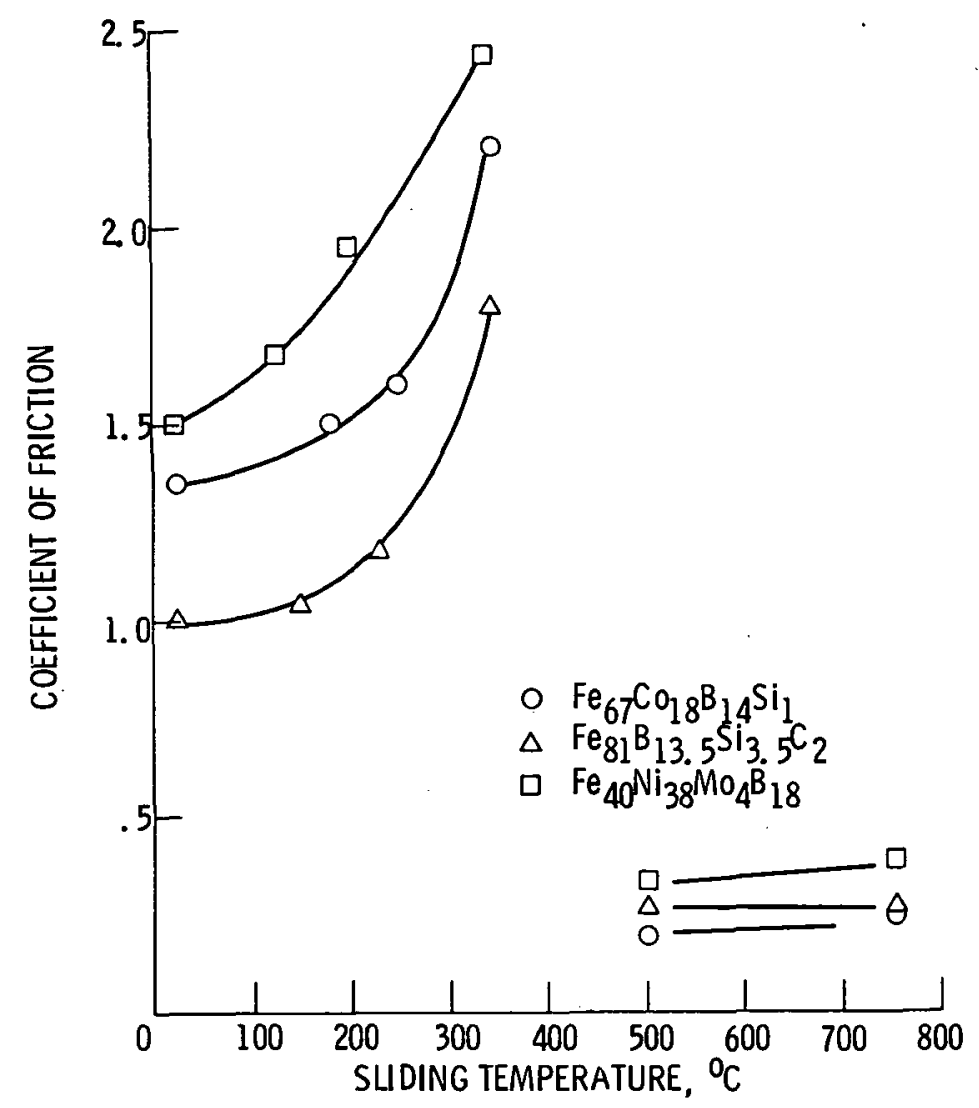

Figure 13. - Coefficient of friction as a function of temperature for aluminum oxide sliding on $\mathrm{Fe}_{6} \mathrm{C}_{\mathrm{C}_{18} \mathrm{Bl}} \mathrm{Bl}$ $\mathrm{Si}_{1}, \mathrm{Fe}_{81} \mathrm{~B}_{13} \mathrm{Si}_{3}{ }_{5} \mathrm{C}_{2}$ and $\mathrm{Fe}_{40} \mathrm{Ni}_{38} \mathrm{Mo}_{4} \mathrm{~B} 18$ in vacuum. Normal load, $0.2 \mathrm{~N}$; sliding velocity, $3 \mathrm{~mm} / \mathrm{min}$; vacuum, $10 \mathrm{nPa}$. 


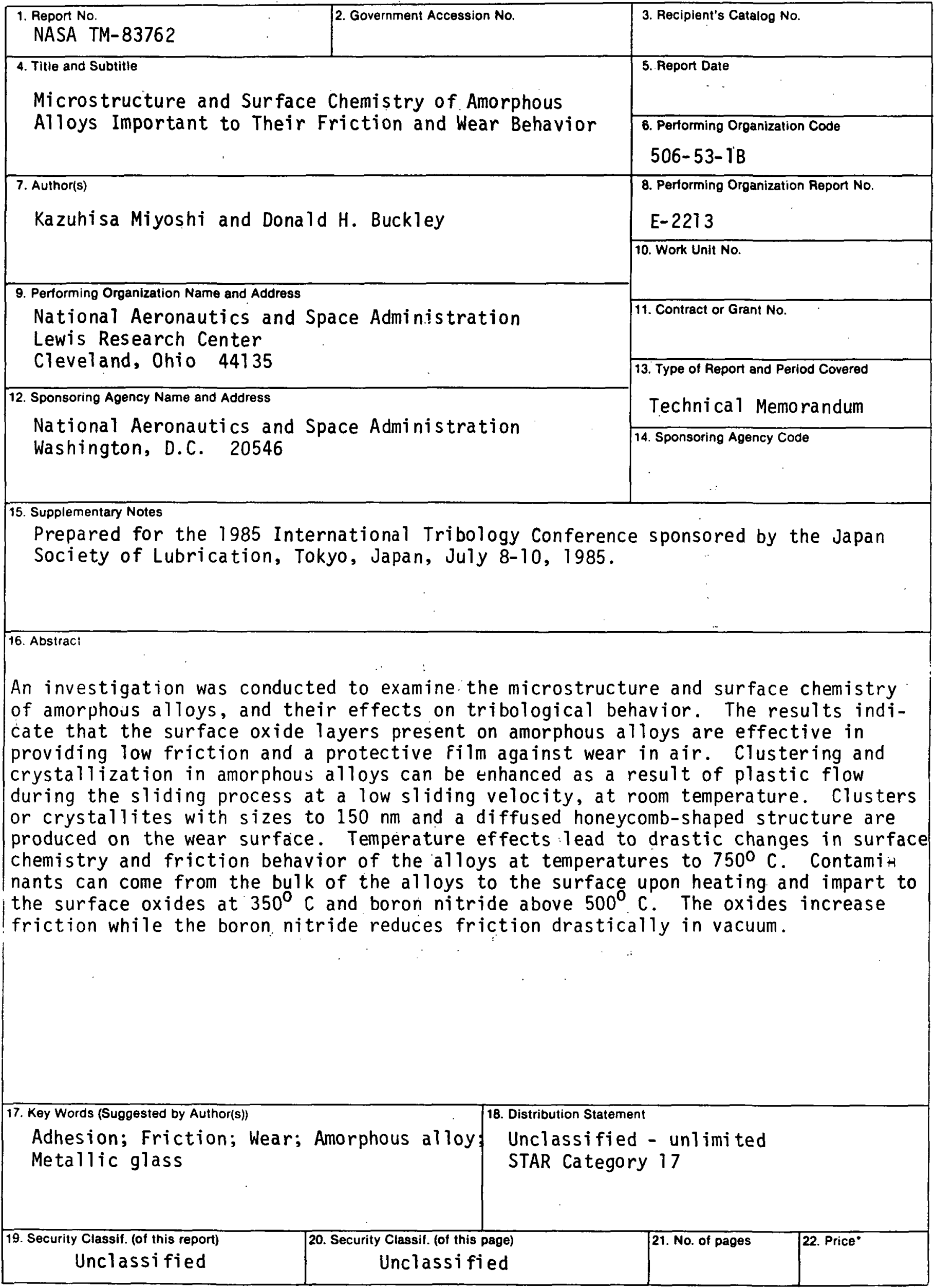

"For sale by the National Technical Information Service, Springfield, Virginia 22161 
National Aeronautics and Space Administration

- Washington, D.C.

20546

Official Business

Penalty for Private Use, $\$ 300$

$\therefore \quad \therefore \quad \therefore$

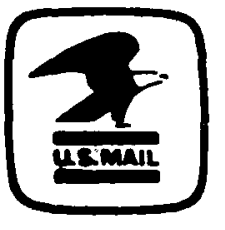

Postage and Fees Paid National Aeronautics and

Space Administrotion NASA-451 